\title{
Comparison of RUSLE and MMF Soil Loss Models and Evaluation of Catchment Scale Best Management Practices for a Mountainous Watershed in India
}

\author{
Susanta Das ${ }^{1}\left(\mathbb{D}\right.$, Proloy Deb ${ }^{2, *(\mathbb{D})}$, Pradip Kumar Bora ${ }^{3} \mathbb{D}$ and Prafull Katre ${ }^{4}$ \\ 1 Department of Soil and Water Engineering, Punjab Agricultural University, Ludhiana, Punjab 141004, India; \\ susanta-swe@pau.edu \\ 2 Centre for Complex Hydrosystems Research, Department of Civil, Construction and \\ Environmental Engineering, The University of Alabama, Tuscaloosa, AL 35487, USA \\ 3 College of Post Graduate Studies, Central Agricultural University, Umiam, Meghalaya 793103, India; \\ pradip66@gmail.com \\ 4 Department of Soil and Water Engineering, Swami Vivekanand College of Agricultural \\ Engineering \& Technology, Indira Gandhi Krishi Vishwavidyalaya, Raipur, Chhattisgarh 492012, India; \\ prafullkatre@rediffmail.com \\ * Correspondence: pdeb1@ua.edu
}

Citation: Das, S.; Deb, P.; Bora, P.K.; Katre, P. Comparison of RUSLE and MMF Soil Loss Models and Evaluation of Catchment Scale Best Management Practices for a Mountainous Watershed in India. Sustainability 2021, 13, 232. https:// doi.org/10.3390/su13010232

Received: 19 September 2020 Accepted: 16 December 2020 Published: 29 December 2020

Publisher's Note: MDPI stays neutral with regard to jurisdictional claims in published maps and institutional affiliations.

Copyright: () 2020 by the authors. Licensee MDPI, Basel, Switzerland. This article is an open access article distributed under the terms and conditions of the Creative Commons Attribution (CC BY) license (https: / / creativecommons.org/ licenses/by/4.0/).

\begin{abstract}
Soil erosion from arable lands removes the top fertile soil layer (comprised of humus/organic matter) and therefore requires fertilizer application which affects the overall sustainability. Hence, determination of soil erosion from arable lands is crucial to planning conservation measures. A modeling approach is a suitable alternative to estimate soil loss in ungauged catchments. Soil erosion primarily depends on soil texture, structure, infiltration, topography, land uses, and other erosive forces like water and wind. By analyzing these parameters, coupled with geospatial tools, models can estimate storm wise and annual average soil losses. In this study, a hilly watershed called Nongpoh was considered with the objective of prioritizing critical erosion hazard areas within the micro-catchment based on average annual soil loss and land use and land cover and making appropriate management plans for the prioritized areas. Two soil erosion models namely Revised Universal Soil Loss Equation (RUSLE) and Modified Morgan-Morgan-Finney (MMF) models were used to estimate soil loss with the input parameters extracted from satellite information and automatic weather stations. The RUSLE and MMF models showed similar results in estimating soil loss, except the MMF model estimated 7.74\% less soil loss than the RUSLE model from the watershed. The results also indicated that the study area is under severe erosion class, whereas agricultural land, open forest area, and scrubland were prioritized most erosion prone areas within the watershed. Based on prioritization, best management plans were developed at catchment scale for reducing soil loss. These findings and the methodology employed can be widely used in mountainous to hilly watersheds around the world for identifying best management practices (BMP).
\end{abstract}

Keywords: soil erosion; LULC; RUSLE; MMF; prioritization and management plan

\section{Introduction}

Soil loss resulting from erosion is a universal issue which affects agricultural production and natural resources [1,2]. Degradation of soil physical properties by soil erosion can affect the crop growth and yield by reducing the root depth, available water, and nutrient reserves, and also by affecting soil organic carbon, phosphorus, potassium, nitrogen contents, and $\mathrm{pH}$ [3]. It also carries soil-laden water downstream, which can produce heavy deposits of sediment that prevent the smooth flow of rivers and streams and can eventually lead to floods [2]. Soil erosion occurs when soil particles are carried off by water or wind and deposited elsewhere. Water erosion begins once rain or irrigation water detaches soil particles. Once there is an excessive amount of water on the soil surface, 
it fills surface depressions and begins to flow with enough speed; this surface runoff carries away the loose soil.

The erosion process is influenced by numerous factors, primarily anthropogenic, such as urbanization and mining, and by natural causes, such as flash floods, and rainstorms $[2,4,5]$. The estimation of these factors is crucial to grasp the individual impact of the factors and establish the crucial sub-watershed in order for proper management and conservation measures to be planned to mitigate erosion [6]. As soil erosion is a continuous process and is non-linear in nature, the assessment of its environmental impact is ambiguous. In order to address this non-linearity, several complex biophysical developments (in terms of modeling) have been done. However, it is still uncertain how and where the soil erosion occurs [7]. Additionally, soil erosion is proportional to population growth, overuse of natural resources, degraded land, and poor water management plans [8-10]. A prerequisite of soil conservation is the reversal of land desertion and the enhancement of agricultural production, the provision of food sanctuary, and sustainability, thereby requiring identification of critical erosion prone areas. In addition to soil degradation, other difficulties caused by soil erosion include removal of soil nutrients, decline of crop yields, reduction of soil fertility, and contamination of surface and groundwater supplies by fertilizer nutrients, sediment, and insecticide residues [4].

Numerous methods are available for quantifying soil erosion. These methods are generally physical or experimental/laboratory scale models [11,12]. The Water Erosion Prediction Project (WEPP) [13], the European Soil Erosion Model (EUROSEM) [6], and the Limburg Soil Erosion Model (LISEM) [14] have mainly used physical-based models. Since these methods are based on actual procedures, they require a large number of input parameters with comprehensive computation. Therefore, simulation of these for a particular area requires data on the observed sediment loss which are not available for ungauged watersheds and in many developing and less developed countries [15]. On the other hand, empirical models such as Universal Soil Loss Equation (USLE) [16], Modified Morgan-MorganFinney (MMF) [17], and Revised Universal Soil Loss Equation (RUSLE) [18] provide an alternative to relate the soil loss to several physical components which are relatively easy to calculate/estimate.

Unlike USLE which inherits a number of limitations including point scale soil loss estimation and mainly targeted for agricultural lands, RUSLE has the advantage of integrating remote sensing (RS) and geographic information systems (GIS) to assess the risk of potential soil erosion at a spatial scale $[19,20]$. This empirical approach is widely accepted by the soil erosion community due to its simplicity and limited data requirement $[4,21-25]$. GIS information layers as well as, rainfall erosivity $(\mathrm{R})$, soil erodibility $(\mathrm{K})$, slope length and gradient (LS), crop management (C), and conservation practice (P) factors can be integrated within the ArcGIS platform to evaluate the collaborative influence on the average annual soil loss.

Similarly, the MMF model is another model like RUSLE, which is aimed at making much use of the physically based concept provided by Meyer and Wischmeier (1969) [26] as compared to the USLE $[16,27]$. The modified MMF model separates the eroding method into two sections: the water phase and the sediment phase. The water phase determines the energy of rain offered to detach soil particles from the soil mass and carried with the surface runoff. The erosion phase regulates the rate of soil particle detachment by rain and runoff and is determined in conjunction with the transport capability of runoff $[17,28-30]$. This model is highly sensitive to the annual rain and soil parameters, once erosion is transport-limited [17]. Mapping of soil erodibility at a spatial scale is possible by integrating RS and GIS techniques with RUSLE and MMF models, which can be further used in identifying the potential risk of soil erosion at a larger geographical extent. The formulation of correct soil management for property development needs a precise inventory and rating of vulnerable areas. These data are incredibly helpful within the higher cognitive process context to avoid land degradation in erosion risk areas, or, as an alternative, to suggest conservation measures to reduce the soil loss if developments continue. 
Given the difference in the model structures and their inherent limitations, it is critical to identify which soil loss model is more suitable for mountainous catchments in India. Therefore, in this study, a peri-urban watershed in high rainfall areas of Meghalaya, which is close to Nongpoh, district headquarters of Ri-Bhoi district, was taken for estimating erosion. The farmers are found to extend their cultivations in many other places within the study watershed. Even some crops like rice, pineapple, and tomato cultivation have been started in the foot hills areas of the watershed. As the study area is a peri-urban watershed with a high degree of slope and the site usually receives a high amount of rainfall, there is clearly pressure on the natural resources of watershed. Given the high slope aided with high rainfall combined with anthropogenic activities, the study area (and also the entire Meghalaya state) is losing the fertile topsoil layer contributing to the deterioration of soil health from an agricultural perspective [31,32]. Hence it has become paramount to quantify the soil loss and make the best management plan for maintaining the sustainability of the land and improving the agricultural production in the study area. Both RUSLE and MMF models were used for estimating soil erosion and identifying the erosion prone areas with the following objectives: (1) to prioritize the critical erosion hazard areas within the micro-catchment based on average annual soil loss, land use, and land cover, and (2) to make the appropriate management plans for the prioritized area. The findings of this study will aid in developing best management practice plans for the watershed for maintaining overall agricultural sustainability by improving soil health and reducing the application of fertilizers/manures for enhanced crop yields.

\section{Materials and Methods}

\subsection{Description of the Study Area}

The study area is a micro-catchment situated at Nongpoh of Ri-Bhoi district, Meghalaya. The study area lies between $25^{\circ} 54^{\prime} 0^{\prime \prime}$ to $25^{\circ} 55^{\prime} 05^{\prime \prime} \mathrm{N}$ latitude and $91^{\circ} 52^{\prime} 54.7^{\prime \prime}$ to 91 $54^{\prime} 17.7^{\prime \prime}$ E longitude and it covers an area of 268 ha $\left(2.68 \mathrm{~km}^{2}\right)$. The study area falls under a humid subtropical climate. The area receives a mean annual rainfall of about $2700 \mathrm{~mm}, 77 \%$ of which is received from July to September [33]. The study area has an average elevation of $469-760 \mathrm{~m}$ above the mean sea level (MSL). The relief is moderate to steeply sloping and the drainage condition varies from well drained in upland areas to poorly drained in low lying areas. The location of the study area is shown in Figure 1. Additionally, Table 1 illustrates the mean monthly and average annual precipitation at four different rain gauges near the micro-catchment. The average precipitation values were derived for a period of 9 years, i.e., 2010-2019. Figure 2 showcases the severity of soil erosion in the study catchment.

The Nongpoh micro-catchment is classified into seven slope classes i.e., flat (0-3\%), undulating (3-8\%), moderately slope $(8-15 \%)$, hilly $105{ }^{\circ} \mathrm{C}$ for $24 \mathrm{~h}$ and then samples were weighted, (15-30\%), moderately steep slope (30-45\%), steep slope (45-60\%), and very steep slope $(>60 \%)$ as per the recommendations of Lee and Silalahi et al. [34,35]. The slope map of Nongpoh micro-catchment is displayed in Figure 3a. Additionally, Figure 3b displays the hypsometric map of the study area. It can be seen that the contours representing higher elevation (ranging from 540 to 760) are more dominant in the edges of the catchment. 


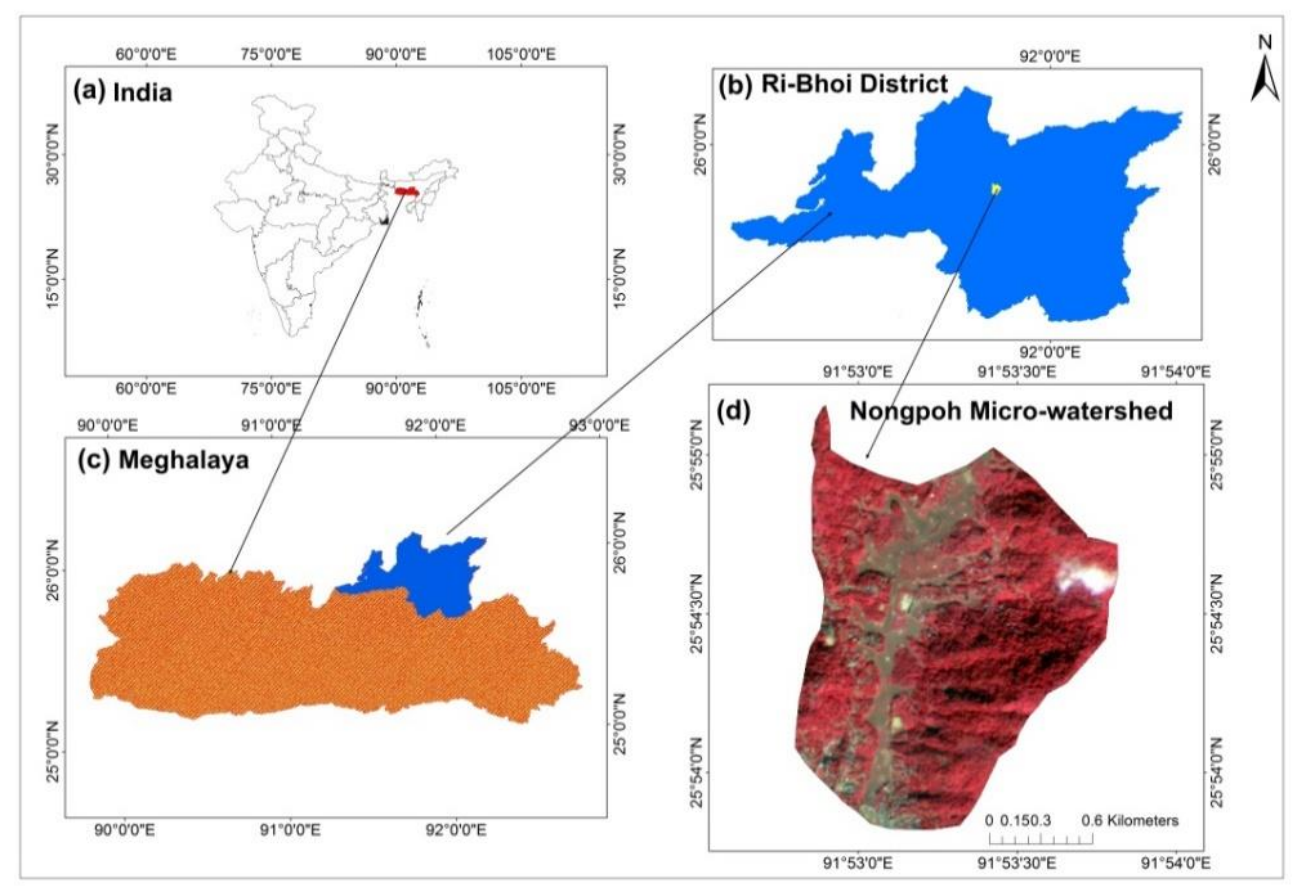

Figure 1. (a) India, (b) Meghalaya, (c) Ri-Bhoi District, and (d) Nongpoh micro-catchment.

Table 1. Mean monthly and average annual rainfall $(\mathrm{mm})$ of stations in the study area.

\begin{tabular}{ccccc}
\hline Month & Byrnihat $(\mathbf{m m})$ & Nongpoh $(\mathbf{m m})$ & Umsining $(\mathbf{m m})$ & NESAC * $(\mathbf{m m})$ \\
\hline January & 6.91 & 16.91 & 18.75 & 16.33 \\
February & 12.16 & 20.16 & 20.25 & 25.21 \\
March & 45.78 & 48.79 & 42.25 & 59.25 \\
April & 134.62 & 126.55 & 51.75 & 98.60 \\
May & 244.35 & 204.00 & 239.25 & 428.60 \\
June & 547.80 & 580.80 & 527.75 & 430.20 \\
July & 581.49 & 615.35 & 575.75 & 572.20 \\
August & 528.62 & 548.62 & 455.25 & 510.25 \\
September & 418.25 & 413.25 & 396.25 & 492.25 \\
October & 136.73 & 146.73 & 149.50 & 170.50 \\
November & 12.43 & 14.42 & 13.25 & 37.33 \\
December & 10.72 & 19.21 & 18.50 & 14.67 \\
Yearly & 2679.86 & 2754.80 & 2508.50 & 2855.39 \\
\hline
\end{tabular}

${ }^{*}$ NESAC stands for North-Eastern Space Applications Centre.
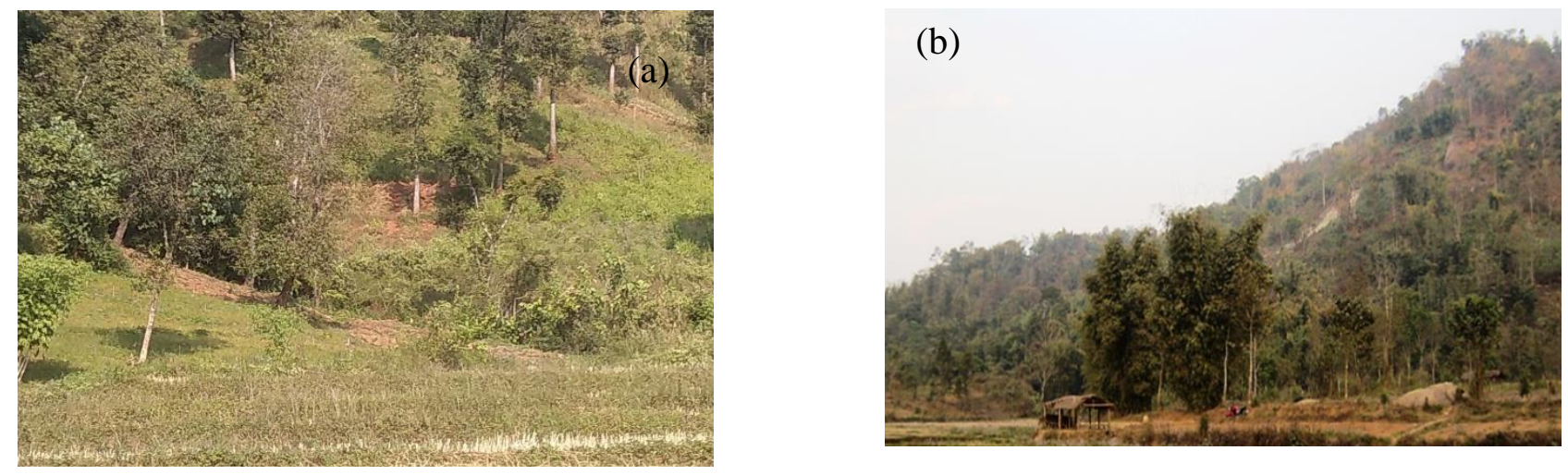

Figure 2. Cont. 

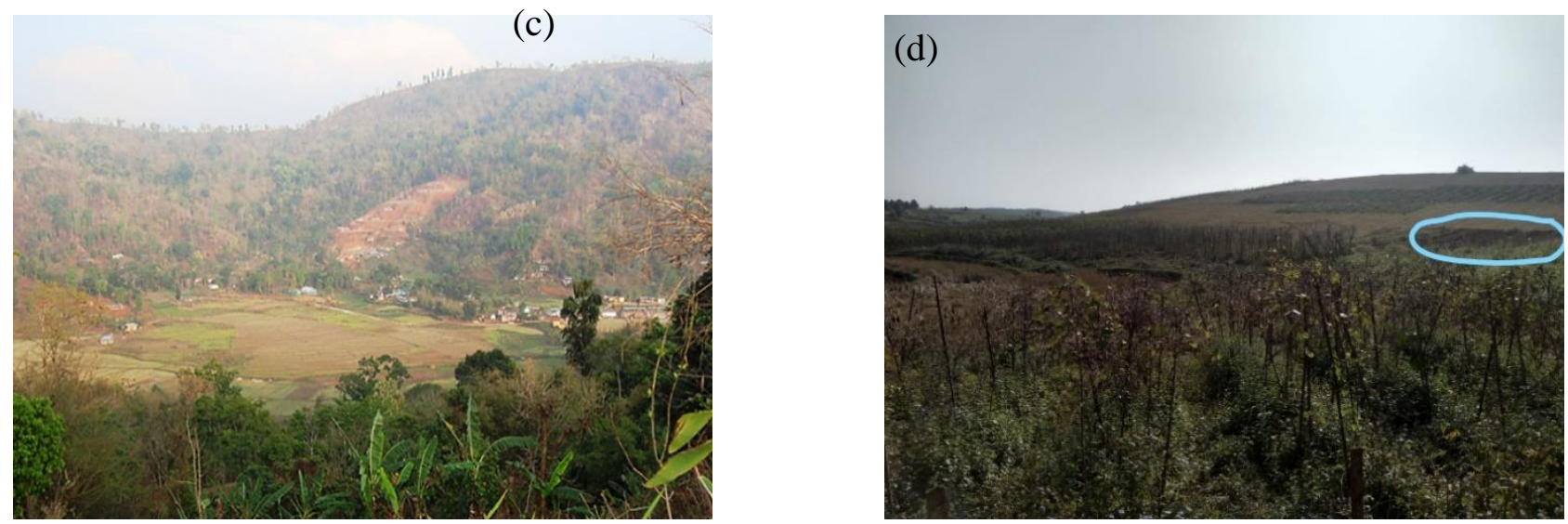

Figure 2. Severity of soil erosion in (a) open forest; (b) dense forest; (c) settlement; and (d) agriculture land use classes at the study catchment.
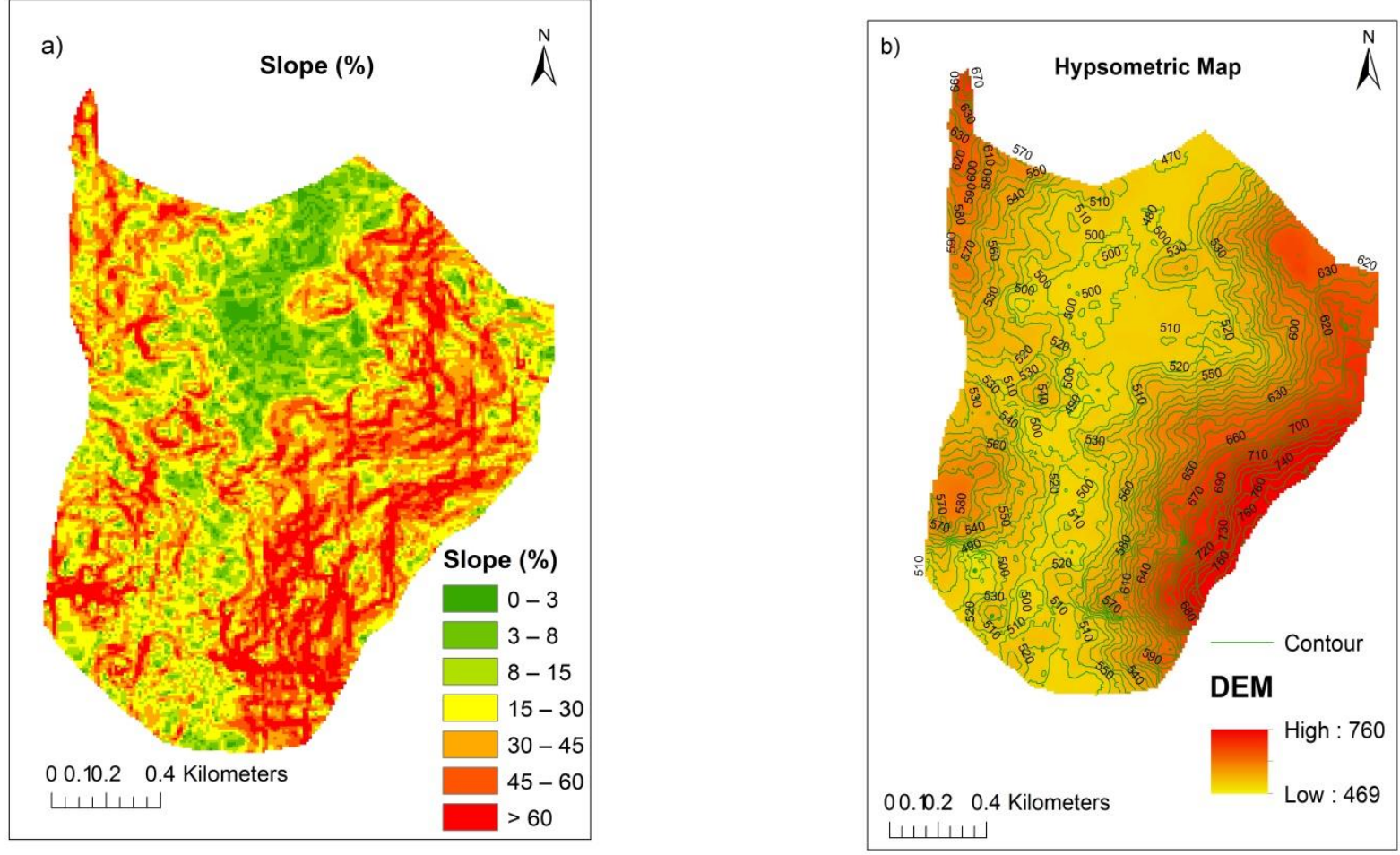

Figure 3. (a) Slope map and (b) hypsometric map of the study area.

The observed soil loss data were obtained for the years 2010-2019 from an ongoing research project of College of Post Graduate Studies (CPGS), Central Agricultural University, Meghalaya, India. After each rainstorm, depth of runoff data were collected at the catchment outlet and, using a measuring cylinder of one liter of water samples, were taken for determination of soil loss. Post-collection of the samples, they were filtered through filter paper of 42 no. grade and the soil was separated from the water. Thereby, the soil was kept in an oven at $105^{\circ} \mathrm{C}$ for $24 \mathrm{~h}$ and then samples were weighed.

The methodological flowchart is given in Figure 4. First, the digital elevation model (DEM) having a spatial resolution of $2.5 \mathrm{~m}$ derived from CARTOSAT-1 (downloaded from Bhuvan, https:/ / bhuvan-app3.nrsc.gov.in/data/download/) was used in identifying the slope and catchment delineation. Additionally, the land use land covers (LULC) for the catchment was derived from the satellite image of Linear Imaging Self-Scanning System IV (LISS-IV) for the year 2015. With the identified characteristics of the catchment and the 
RUSLE and MMF model parameters derived within the catchment, the rate of soil loss for the years 2010 to 2019 year was calculated, which was further used in the model calibration and validation. Moreover, based on the estimated rate of soil erosion, the prioritized micro-catchments were chosen, and using ArcGIS 10.2, several best management practices for reducing soil loss at the micro-catchment were conducted.

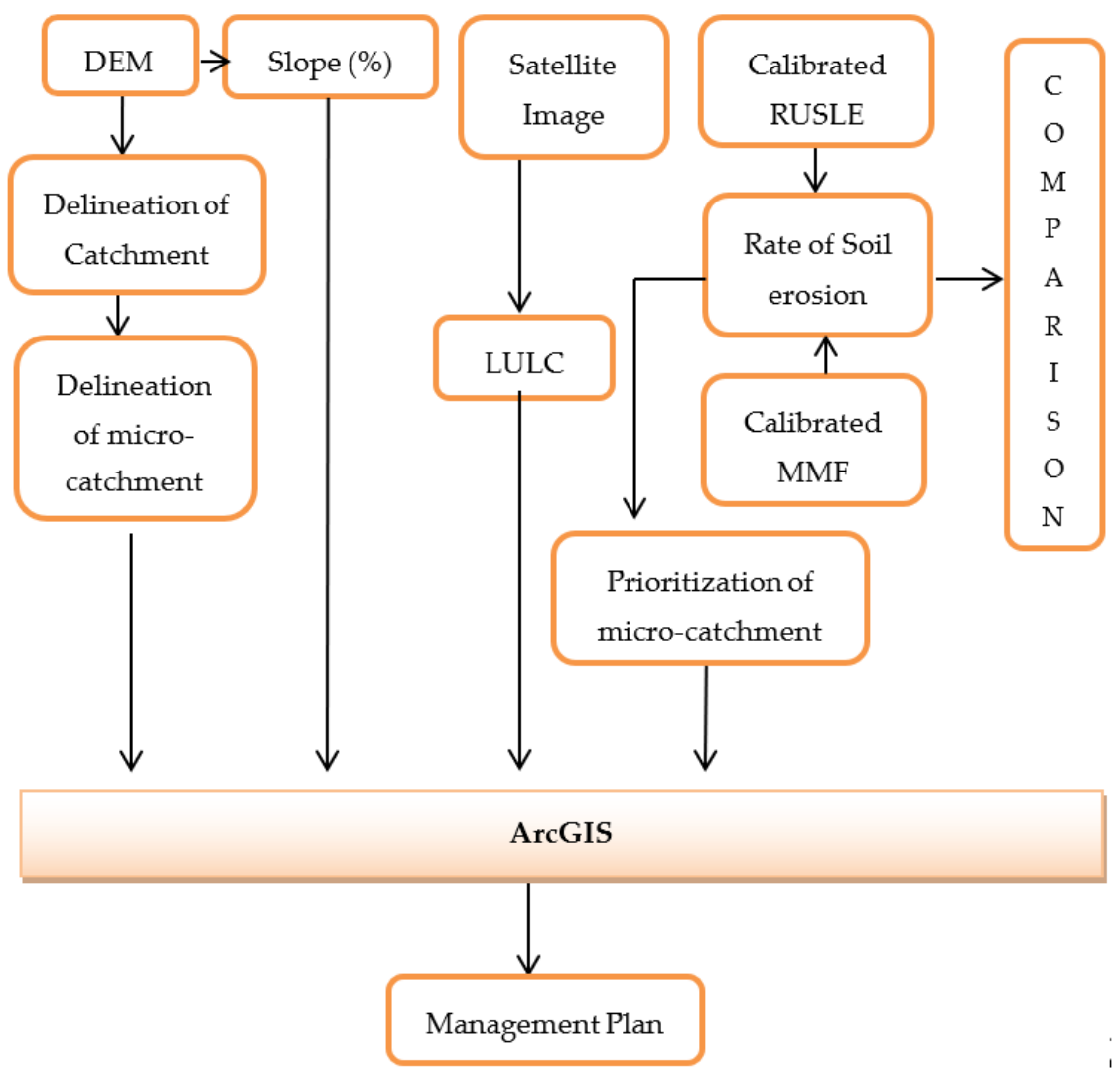

Figure 4. Methodological flowchart of the study.

\subsection{Land Use Land Cover}

Based on tonal and color variation in the satellite imagery (LISS-IV, 8-12-2015) and ground-truthing (supervised classification), the major LULC classes were identified. The spatial distribution of LULC categories, such as contour bunding, agriculture, dense forest, open forest, settlement, scrubland, terrace farming, upland paddy field, waterbody, etc., is prepared by 1:5000 scales. The land use land cover map of Nongpoh is shown in Figure 5 . The data on the statistics of the LULC categories identified in Nongpoh micro-catchment are presented in Table 2.

Table 2. Land use land cover (LULC) classes of the study area.

\begin{tabular}{ccc}
\hline LULC & Area (ha) & Area (\%) \\
\hline Contour bunding & 4.20 & 1.57 \\
Agriculture & 44.29 & 16.52 \\
Dense forest & 78.80 & 29.39 \\
Open forest & 55.15 & 20.57 \\
Settlement & 49.37 & 18.41 \\
Scrubland & 26.48 & 9.88 \\
Terrace farming & 0.19 & 0.07 \\
Upland paddy field & 8.86 & 3.30 \\
Water body & 0.81 & 0.30 \\
Total & 268.15 & 100.00 \\
\hline
\end{tabular}




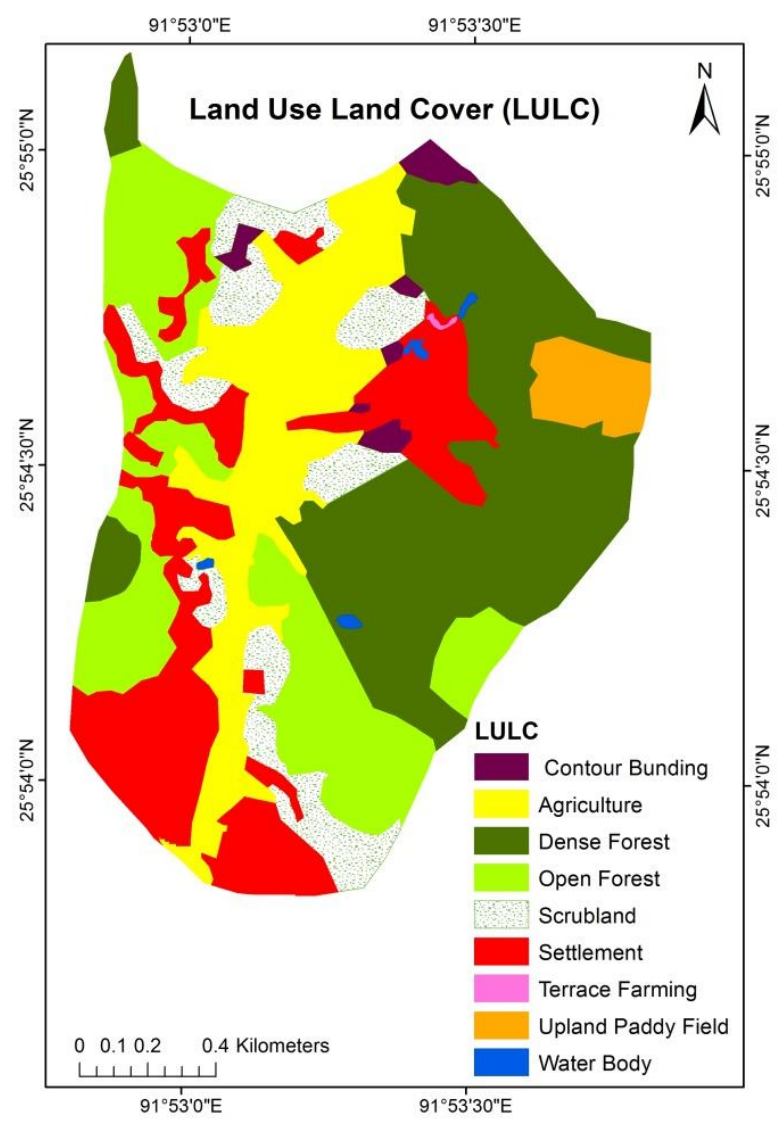

Figure 5. LULC of the study area.

\subsection{Estimation of Soil Loss}

\subsubsection{Revised Universal Soil Loss Equation (RUSLE)}

RUSLE is the method that is the most widely used approach in estimating longterm rates of inter-rill and rill erosion from field or farm size units subject to different management practices. The underlying assumption in RUSLE is that the detachment and deposition are controlled by sediment content in the runoff. The equation has following form, Equation (1).

$$
\mathrm{A}=\mathrm{R} \times \mathrm{K} \times \mathrm{LS} \times \mathrm{C} \times \mathrm{P}
$$

where $\mathrm{A}=$ average annual soil loss $\left(\mathrm{t} \mathrm{h}^{-1} \mathrm{yr}^{-1}\right), \mathrm{R}=$ rainfall and runoff erosivity (MJ mm ha ${ }^{-1} \mathrm{~h}^{-1} \mathrm{yr}^{-1}$ ), $\mathrm{K}=$ soil erodibility factor, $\mathrm{LS}=$ topographic factor, $\mathrm{C}=$ crop management factor, and $\mathrm{P}=$ supporting conservation practice factor.

\section{Rainfall and Runoff Erosivity (R)}

Rainfall plays a significant role in the process of soil erosion and sedimentation, and this ultimately contributes to water erosion including splash, sheet, rill, and gully erosion, triggered by water flow. The erosive force of rainfall which causes soil erosion is known as rainfall erosivity factor $(\mathrm{R})$. The data of monthly rainfall (shown in Table 2) and annual rainfall are used for the calculation of $R$ factor using Equation $(2)[17,36]$. The spatial variability of $\mathrm{R}$ is calculated in ArcGIS 10.2 domain using a spatial interpolation tool for the study area.

$$
\mathrm{R}=\sum_{1}^{12} 1.735 \times 10^{\left(1.5 \log _{10}\left(\frac{\mathrm{p}_{\mathrm{i}}^{2}}{\mathrm{P}}-0.08188\right)\right)}
$$

where $\mathrm{p}_{\mathrm{i}}=$ monthly rainfall $(\mathrm{mm})$ and $\mathrm{P}=$ annual rainfall $(\mathrm{mm})$, and $\mathrm{R}=$ Rainfall and runoff erosivity (MJ mm ha ${ }^{-1} \mathrm{~h}^{-1} \mathrm{yr}^{-1}$ ). 


\section{Soil Erodibility Factor (K)}

Soil erodibility factor $(\mathrm{K})$ is influenced by the geological characteristics, such as parent material, texture, structure, organic matter content, and porosity of the soil. As silt is the primary particle responsible for soil erosion, erodibility tends to decrease with the decrease of silt particle in the soil, irrespective of \% content of sand and clay [33-37]. For the calculation of $\mathrm{K}$ factor of the study area, the soil physical properties analyses equation [38] was adopted. In this method, physical properties of soil such as soil texture, soil structure, soil permeability, and soil organic matter are used to calculate the $\mathrm{K}$ factor [33]. Other researchers also used this equation $[33,36,37,39,40]$. The soil sample was collected from the 50 different places of the watershed to calculate the physical properties of the soil. The laboratory analysis was done for all the parameters following the procedure of Deb et al. [40], and then this point value was taken in the ArcGIS domain. The K factor was calculated by using raster calculator, spatial interpolation (kriging) technique, and was calculated as in Equation (3).

$$
\mathrm{K}=27.66 \times \mathrm{M}^{1.14} \times 10^{-8} \times(12-\mathrm{a})+0.0043 \times(\mathrm{b}-2)+0.0033 \times(\mathrm{c}-3)
$$

where $\mathrm{K}=$ soil erodibility factor, $\mathrm{M}=($ silt $(\%)+$ very fine sand $(\%) \times(100$-clay $\%))$, $\mathrm{a}=$ organic matter $(\%), \mathrm{b}=$ soil structure, and $\mathrm{c}=$ soil permeability $(1$-rapid, 2 -moderate to rapid, 3-moderate, 4-moderate to slow, 5-slow, and 6-very slow].

\section{Topographic Factor (LS)}

The LS factor represents the ratio of soil loss on a given slope length and steepness to soil loss from a slope that has a length of $22.1 \mathrm{~m}$ and steepness of $9 \%$, where all other conditions are the same [35]. The LS factor is not an absolute value, instead is referenced to unity at $22.1 \mathrm{~m}$ slope length and $9 \%$ steepness, and hence provides significant information on the susceptibility of the terrain to soil erosion. The LS factor was computed $[16,35]$ using the Equation (4).

$$
\mathrm{LS}=\left(\frac{\lambda}{22.13}\right)^{\mathrm{m}} \times\left(0.065+0.045 \mathrm{~S}+0.0065 \mathrm{~S}^{2}\right)
$$

where $\lambda=$ slope length $(\mathrm{m}), \mathrm{S}=$ angle of slope $(\%), \mathrm{m}$ is the constant dependent on the value of the slope gradient; 0.5 if the slope angle is greater than $5 \%, 0.4$ on slopes of $3 \%$ to $5 \%, 0.3$ on slopes of 1 to $3 \%$, and 0.2 on slopes less than $1 \%$.

\section{Crop Management Factor $(\mathrm{C})$}

The crop management factor $(\mathrm{C})$ is used to determine the relative effectiveness of soil and crop management systems in terms of preventing soil loss and it mainly depends on vegetation canopy. The $C$ factor was calculated using the normalized difference vegetation index (NDVI) suggested by van der Knijff et al. [41] and is given in Equation (5).

$$
C=\exp \left[\alpha \frac{\mathrm{NDVI}}{(\beta-\mathrm{NDVI})}\right]
$$

where $\alpha$ and $\beta$ are unitless parameters that determine the shape of the curve relating to NDVI and the C factor. Van der Knijff et al. [41] found that this scaling approach gave better results than assuming a linear relationship, and the values of 2 and 1 were selected for the parameters $\alpha$ and $\beta$, respectively.

\section{Conservation Practice (P)}

$P$ factor reflects the effects of practices that reduce the amount and rate of water runoff and ultimately reduce the amount of erosion. The most important supporting practices are contour tillage, strip-cropping on the contour, and terrace systems. The $\mathrm{P}$ value ranges from 0 to 1 , where 0 represents a very good manmade erosion resistance facility and 1 represents 
no manmade erosion resistance facility [34]. The spatial variability of input parameters of RUSLE model was calculated in ArcGIS 10.2 domain using spatial interpolation and raster calculator tool.

\subsubsection{Modified Morgan-Morgan-Finney (MMF) Model}

The Morgan-Morgan-Finney (MMF) model [26] was developed to predict soil loss from field-sized slopes. This model is flexible, simple, and also needs less data than other physically based soil erosion models [38]. The Modified MMF model separates the soil erosion process into two phases: the water phase and the sediment phase $[17,28]$. The water phase determines the energy of rain offered to detach soil particles from the soil mass and carried with the surface runoff. In the erosion phase, rates of soil particle detachment by rainfall and runoff were determined and also the transport capacity (TC) by runoff was calculated [28]. TC was determined by using the slope steepness, volume of overland flow, and the cover management factor (C). Improvements were made in modified MMF in the simulation of soil detachability due to precipitation, which considers leaf drainage and fall from the plant canopy.

\section{Water Phase}

Calculation of different variables within the water phase were completed using Equations (6)-(14). Equations (6)-(11) were used to calculate the kinetic energy associated with rainfall within the micro-catchment, whereas, Equations (12)-(14) were used to estimate the runoff at the micro-catchment outlet. The mean yearly rainfall was used to estimate the kinetic energy of raindrop splash and overland flow for detachment of soil particle. The total energy of rainfall was estimated by applying the intensity of rainfall and kinetic energy relationship proposed by Wischmeier and Smith (1978) [27].

$$
E R=R(1-A)
$$

where $\mathrm{R}=$ mean annual rainfall $(\mathrm{mm}), \mathrm{ER}=$ effective rainfall $(\mathrm{mm})$, and $\mathrm{A}=$ proportion (between 0 and 1 ) of the rainfall intercepted by the vegetation or crop cover.

$$
\mathrm{LD}=\mathrm{ER} \times \mathrm{CC}
$$

where $\mathrm{LD}=$ leaf drainage $(\mathrm{mm})$ and $\mathrm{CC}=$ proportion of canopy cover (between 0 and 1 ).

$$
\mathrm{DT}=\mathrm{ER}-\mathrm{LD}
$$

where DT = direct through fall $(\mathrm{mm})$.

$$
\mathrm{KE}(\mathrm{DT})=\mathrm{DT}(11.9+8.7 \log \mathrm{I})
$$

where $\mathrm{I}=$ rainfall intensity $(\mathrm{mm} / \mathrm{hr})$ and $\mathrm{KE}(\mathrm{DT})=$ kinetic energy of the direct throughfall $\left(\mathrm{J} \mathrm{m}^{-2}\right)$.

$$
\mathrm{KE}(\mathrm{LD})=\mathrm{LD}\left\{\left(15.8-\mathrm{PH}^{0.5}\right)-5.87\right\}
$$

where $\mathrm{KE}(\mathrm{LD})=$ kinetic energy of the leaf drainage $\left(\mathrm{J} \mathrm{m}^{-2}\right)$ and $\mathrm{PH}=$ height of the plant canopy (m).

$$
\mathrm{KE}=\mathrm{KE}(\mathrm{DT})+\mathrm{KE}(\mathrm{LD})
$$

where $\mathrm{KE}=$ kinetic energy of the rainfall $\left(\mathrm{J} \mathrm{m}^{-2}\right)$.

Runoff occurs when the daily precipitation exceeds the soil moisture storage capacity and indicates the moisture storage ability of the soil-crop system.

$$
\mathrm{Q}=\mathrm{R} \exp \left(-\mathrm{R}_{\mathrm{c}} / \mathrm{R}_{\mathrm{o}}\right)
$$


where $Q=$ volume of overland flow $(\mathrm{mm}), R_{c}=$ storage capacity of soil moisture $(\mathrm{mm})$, and $R_{O}=$ ratio between yearly rainfall and the number of rainy days.

$$
\mathrm{R}_{\mathrm{C}}=1000 \mathrm{MS} \operatorname{BD} \operatorname{EHD}\left(\mathrm{E}_{\mathrm{t}} / \mathrm{E}_{\mathrm{o}}\right)^{0.5}
$$

where MS = moisture content at field capacity or $1 / 3$ bar tension, $\mathrm{BD}=$ bulk density of the topsoil layer $\left(\mathrm{Mg} \mathrm{m}^{-3}\right), \mathrm{EHD}=$ effective hydrological depth of soil $(\mathrm{m}), \mathrm{E}_{\mathrm{t}}=$ actual evapotranspiration $(\mathrm{mm})$, and $\mathrm{E}_{0}=$ potential evapotranspiration $(\mathrm{mm})$.

$$
\mathrm{R}_{\mathrm{O}}=\mathrm{R} / \mathrm{R}_{\mathrm{n}}
$$

where $R_{n}=$ number of rainy days.

Sediment Phase

Soil erosion is primarily caused by the soil particle detachment from soil mass due to splashing or raindrops impact, and the soil particle being moved by the overland flow. The soil detachment caused by splash is a function of rainfall energy, soil erodibility, and the rainfall intercepted by vegetation. Rainfall energy on the surface of the ground decreases exponentially with the increase of interception rate [42,43]. The model compares the expected splash detachment rate with the overland transport efficiency, which equals the soil erosion rate to less than two values, therefore showing if the detachment is a restrictive factor. The soil transport capacity of the overland flow or runoff was established with the overland flow rate, slope, and crop management $[17,28]$. The calculations of different parameters in the sediment phase were completed using Equations (15)-(19).

The detachment rate by splash is mainly influenced by the soil erodibility $(\mathrm{K})$ and was calculated to be the weight of soil particles detached from the soil mass per unit of rainfall energy. This is calculated by using Equation (15).

$$
\mathrm{F}=\mathrm{K} \times \mathrm{KE} \times 10^{-3}
$$

where $\mathrm{F}=$ annual rate of soil particle detachment by raindrop impact $\left(\mathrm{kg} \mathrm{m}^{-2}\right), \mathrm{K}=$ soil erodibility factor, and $\mathrm{KE}=$ kinetic energy of rainfall.

Transport capacity of the overland flow is influenced by the slope factor, volume of the overland flow, and the ground cover management (GC) factor. The slope factor and ground cover management factor were calculated from the satellite images in ArcGIS 10.2 domain.

$$
\mathrm{H}=\mathrm{Z} \times \mathrm{Q}^{1.5} \sin \mathrm{S} \times(1-\mathrm{GC}) \times 10^{-3}
$$

where $\mathrm{H}=$ annual rate of soil particle detachment by runoff $\left(\mathrm{kg} \mathrm{m}^{-2}\right)$ and $\mathrm{GC}=$ ground cover $(\%)$.

$$
\mathrm{Z}=1 /(0.5 \mathrm{COH})
$$

where $\mathrm{Z}$ is constant for runoff detachment, dependent on soil cohesion, and $\mathrm{COH}=$ cohesion of soil in $\mathrm{kPa}$.

$$
\mathrm{J}=\mathrm{F}+\mathrm{Z}
$$

where $\mathrm{J}=$ annual rate of total soil particle detachment $\left(\mathrm{kg} \mathrm{m}^{-2}\right)$.

$$
\mathrm{TC}=\mathrm{C} \times \mathrm{Q}^{2} \sin \mathrm{S} \times 10^{-3}
$$

where TC = annual transport capacity of overland flow $\left(\mathrm{kg} \mathrm{m}^{-2}\right), \mathrm{C}=$ crop cover factor, and $\mathrm{S}=$ slope steepness in degree.

The MMF model compared the rate of predicted splash detachment with the transport capacity by runoff or overland flow, and the lower value of both approaches was used as the rate of soil erosion $[16,25]$. The spatial variations over the area of all the MMF parameters were calculated with the help of ArcGIS 10.2 tools. 


\subsection{Calibration and Validation}

The calibration and validation for both the models (RUSLE and MMF) were done for the years of 2010 to 2015 and 2016 to 2019 soil erosion data, respectively. The RUSLE calibration was done by taking the parameters like R, K, LS, C and P data from year 2010-2015 in spatial domain using ArcGIS. Values of all the parameters except $C$ were not much changing for the calibration periods. We observed that as the land use of mainly agricultural activity changes, then the value of $C$ factor also changed. Then, the $C$ factor was calibrated manually by altering the $\alpha$ and $\beta$ parameters using the trial-and-error approach with the starting values of 2 and 1 for $\alpha$ and $\beta$, respectively, as suggested by van der Knijff et al. [41]. Similarly, the calibration parameter for the MMF model was plant height $(\mathrm{PH})$, which varies with land use type, and therefore for each land use classification the parameter value $\mathrm{PH}$ was optimized. The optimal value of $\mathrm{PH}$ was also identified in a similar approach as that of $\alpha$ and $\beta$ parameters for RUSLE model. Following identification of the optimal values of the model parameters, the model was simulated for the validation period to evaluate the model performance relative to the observed soil loss at the microcatchment outlet.

\subsection{Preparation of Best Management Plan (BMP) or Alternative Land Use Land Covers (ALULC)}

The best management plan (BMP) or alternative land use land covers (ALULCs) was prepared for the prioritized areas by considering the high soil erosion rate $(>40 \mathrm{t} / \mathrm{ha} / \mathrm{yr})$ areas within the micro-catchment, existing LULC, and slope (\%). In this study, the conditions for different LULCs such as, if there is an open forest and agricultural land which have a slope of $0-8 \%$ and contribute to high soil erosion, then the suggestion was done for graded/contour bunding in the area. Similarly, for the agricultural and scrubland areas having a slope within the range of $8-33 \%$ and being observed to contribute to high soil erosion, then the recommendation was done for terracing. Likewise, for the areas having agriculture, open forest, and scrubland with a slope more than $33 \%$ and contributing to high soil erosion, afforestation was advised. Finally, for only agricultural areas having a slope of $0-8 \%$ and contributing to low soil erosion, intensive agriculture was suggested. These ALULCs were determined based on the suggestions of Srivastava et al. [44]. These suggested ALULCs were then plotted in ArcGIS environment to demonstrate a spatial map for robust planning to combat soil erosion. It is to be noted that these ALULCs were only suggested for the above-mentioned LULC classes, and the dense forest and settlement LULCs were not considered. Moreover, the output of the RUSLE approach was used in recommending the ALULC.

\section{Results}

The results obtained from field data, laboratory analyses, and analyses of models for prediction of soil loss at the micro-catchment of Nongpoh are presented.

\subsection{Calibration and Validation of RUSLE and MMF Models}

As mentioned earlier, the RUSLE and MMF models were calibrated and validated against six years (2010-2015) and four years (2016-2019) of observed annual soil erosion data, respectively. During the calibration of RUSLE model, the simulated and observed average annual soil erosion was found to be 59.91 and $58.22 \mathrm{t} / \mathrm{ha} / \mathrm{yr}$ respectively. The calibration parameters $\alpha$ and $\beta$ of the RUSLE model were found to be 2.06 and 0.97 with the standard deviation of 0.17 and 0.08 , respectively. Similarly, during the validation period of the RUSLE model, the average simulated and observed annual soil erosion were noted to be 59.97 and $61.93 \mathrm{t} / \mathrm{ha} / \mathrm{yr}$, respectively. As the calibration parameter for the MMF model is plant height, the mean plant height results for the different land use pattern are presented in Figure 6. Clearly, the average plant height for agriculture (which is generally paddy) was $0.97 \mathrm{~m}$; dense forest corresponded to the subtropical forests with an average height of $23.54 \mathrm{~m}$. Mean plant height for upland paddy field was found to be $0.92 \mathrm{~m}$ (Figure 6). These optimal values were identified based on literature to match the observed annual 
soil loss. During calibration and validation of the MMF model, the average simulated annual soil erosion was observed to be $54.05 \mathrm{t} / \mathrm{ha} / \mathrm{yr}$ and $55.30 \mathrm{t} / \mathrm{ha} / \mathrm{yr}$, respectively. Figure 7 displays the scatter plot of the observed against the simulated soil loss by RUSLE and MMF models during calibration and validation. From the figure, it is clear the both models simulate the soil loss in good agreement corresponding to the observed soil loss.

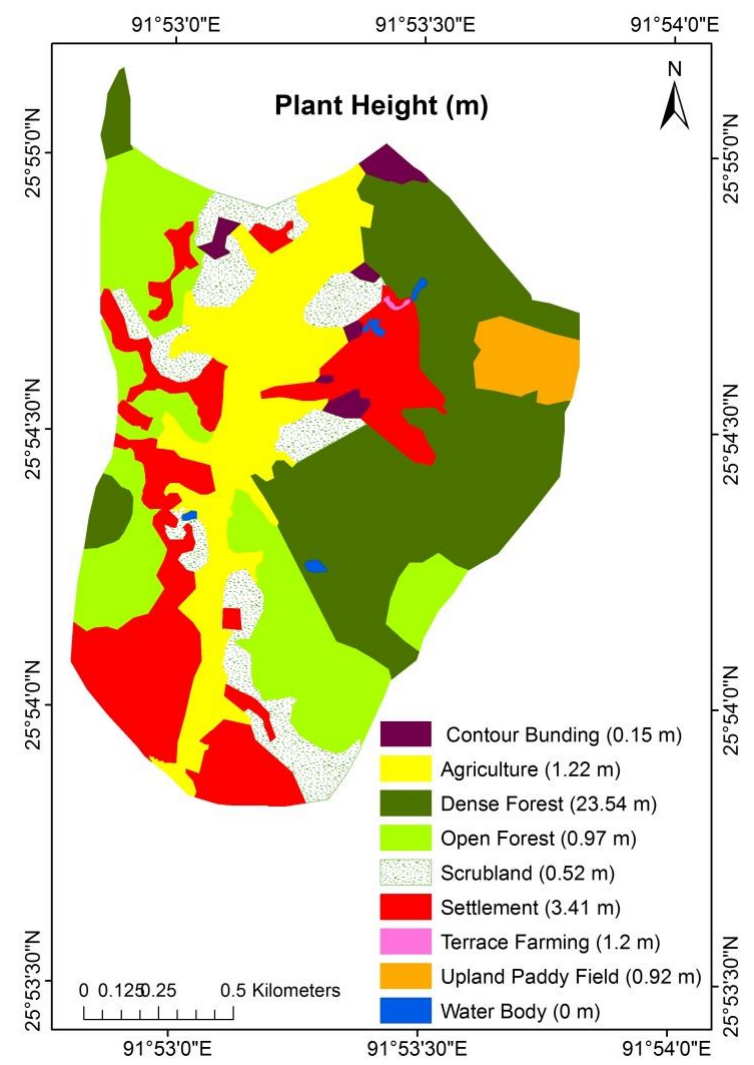

Figure 6. Average plant height (PH), calibration parameter for Morgan-Morgan-Finney (MMF) model.

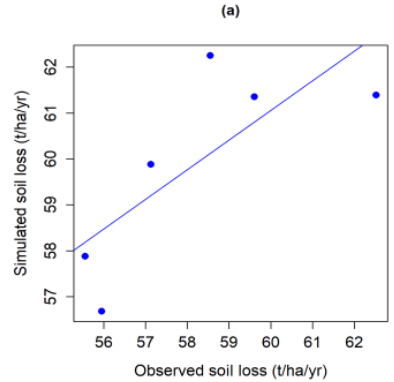

(c)

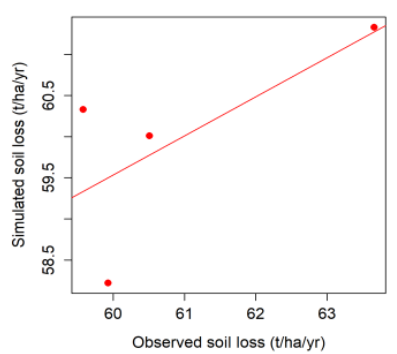

(b)

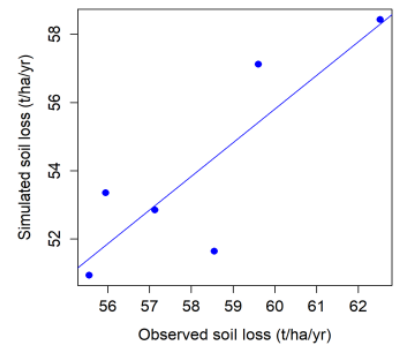

(d)

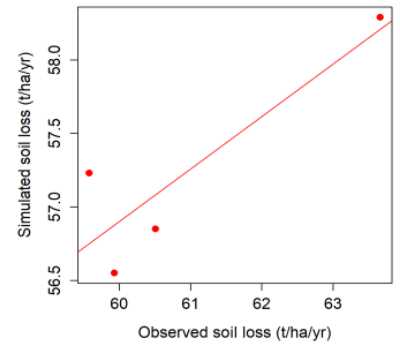

Figure 7. Observed vs. simulated soil loss during calibration of (a) Revised Universal Soil Loss Equation (RUSLE) and (b) MMF models, and validation of (c) RUSLE and (d) MMF models at Nongpoh micro-catchment. 
The model calibration and validation statistics are provided in Table 3. The model simulation results are represented by Nash-Sutcliffe efficiency (NSE), mean absolute error (MAE), and root mean square error (RMSE). The results indicate that during both calibration and validation, the RUSLE model outperformed the MMF model. This was demonstrated by the higher values obtained for NSE, and lower values of MAE and RMSE noted for RUSLE relative to MMF model (Table 3). Nevertheless, given the values are within the ideal range of the observed values (as suggested by Moriasi et al. 2007) [44], both models are well calibrated.

Table 3. RUSLE and MMF model calibration and validation statistics.

\begin{tabular}{ccccc}
\hline Calibration/Validation & Model & NSE & MAE (t/ha/yr) & RMSE (t/ha/yr) \\
\hline \multirow{2}{*}{ Calibration } & RUSLE & 0.82 & 1.68 & 2.29 \\
\cline { 2 - 5 } & MMF & 0.77 & 4.17 & 4.42 \\
\hline \multirow{2}{*}{ Validation } & RUSLE & 0.73 & 0.95 & 1.51 \\
\cline { 2 - 5 } & MMF & 0.71 & 3.69 & 3.85 \\
\hline
\end{tabular}

The following sections discuss the average RUSLE and MMF model variables during the calibration and validation process.

\subsection{RUSLE Model Analysis}

In this study, the RUSLE model, which has six input parameters, was used. For calculating the different input parameters, the meteorological data, soil data, satellite images (LISS-IV), and DEM were used. The values of different input parameters are discussed below.

From the analysis, it was observed that the study area comprises of high $\mathrm{R}$ factor values, lying between 8545.02 to $8782.42 \mathrm{MJ} \mathrm{mm} \mathrm{ha}{ }^{-1} \mathrm{~h}^{-1} \mathrm{yr}^{-1}$ with an average of $8782.42 \mathrm{MJ} \mathrm{mm} \mathrm{ha}{ }^{-1} \mathrm{~h}^{-1} \mathrm{yr}^{-1}$. These high $\mathrm{R}$ values are due to high rainfall received in the study area which directly influences the soil erosion. The $\mathrm{R}$ factor was calculated from the point rainfall and then it was interpolated for the entire study watershed. The average $R$ factor during its calibration and its spatial variability is shown in Figure 8a. Similarly, the K value is mainly influenced by the soil physical parameters and it is generally found to be high for the mountainous watersheds [33,36,37]. The present study also demonstrated the same with higher $\mathrm{K}$ factor values within the catchment ranging from 0.12 to 0.23 with an average value of 0.18 (Figure $8 b$ ).

The spatial distribution of LS factor is also shown in Figure $8 \mathrm{c}$ and it ranged between 0 and 106.24, with an average of 6.05 across the study area. Similarly, the $C$ factor of the study area ranged from 0 to 1 , whereas the dense forest area reflects much lower $C$ values ranging from 0 to 0.12 . Similarly, for agricultural land, $\mathrm{C}$ values ranged from 0.35 to 0.54 . The highest $C$ value was obtained in the areas of wasteland and settlement which ranged from 0.54 to 1 , as shown in Figure $8 d$.

Soil conservation practices $(\mathrm{P})$ were much lower in the study area except for some sporadic bunding and terracing in the agricultural land. The $\mathrm{P}$ value was 0.5 in contour bunding and upland paddy field areas and 0.6 in terrace farming areas, rest were taken as 1 .

From the analysis of RUSLE model, it was found that the mean annual soil loss in the study area ranged from 0 to $1348.08 \mathrm{t} \mathrm{ha}^{-1} \mathrm{yr}^{-1}$ with an average of $59.94 \mathrm{t} \mathrm{ha}^{-1} \mathrm{yr}^{-1}$, which is also falling under severe erosion risk [42,44-46]. From the analysis, it was observed that the agricultural land had the highest soil erosion rate of all the portions of the study area. Figure $9 a, b$ represents the kinetic energy dissipated by raindrop and depth of overland flow respectively. Similarly, Figure 10a,b demonstrates the total soil detachment rate and transport capacity of runoff at the study catchment respective. Additionally, the spatial distribution of soil erosion is shown in Figure 11. 

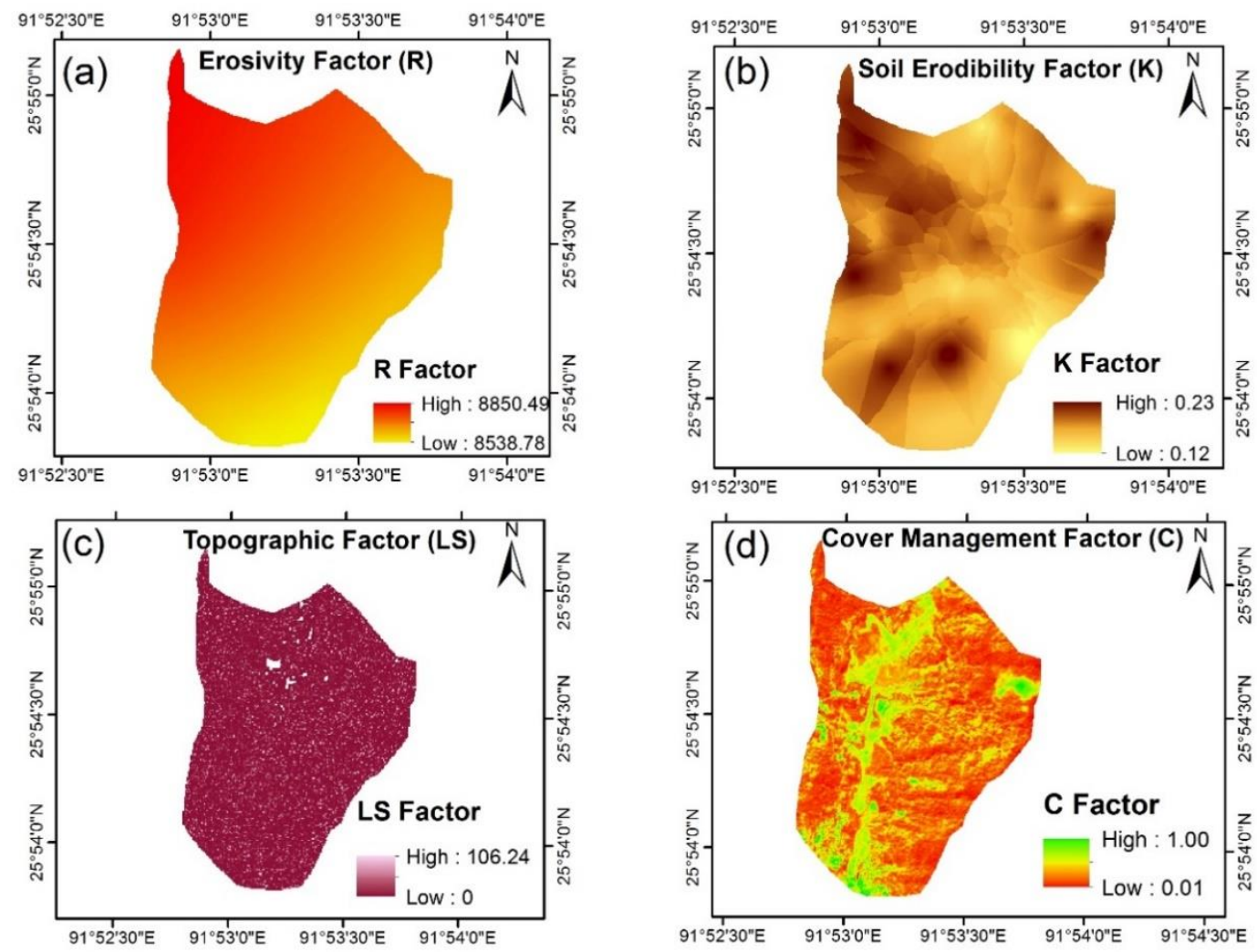

Figure 8. RUSLE (R, K, LS, and C) factors derived for the study area. Note: (a) rainfall runoff erosivity factor, (b) soil erodibility factor, (c) topographic factor and (d) cover management factor.
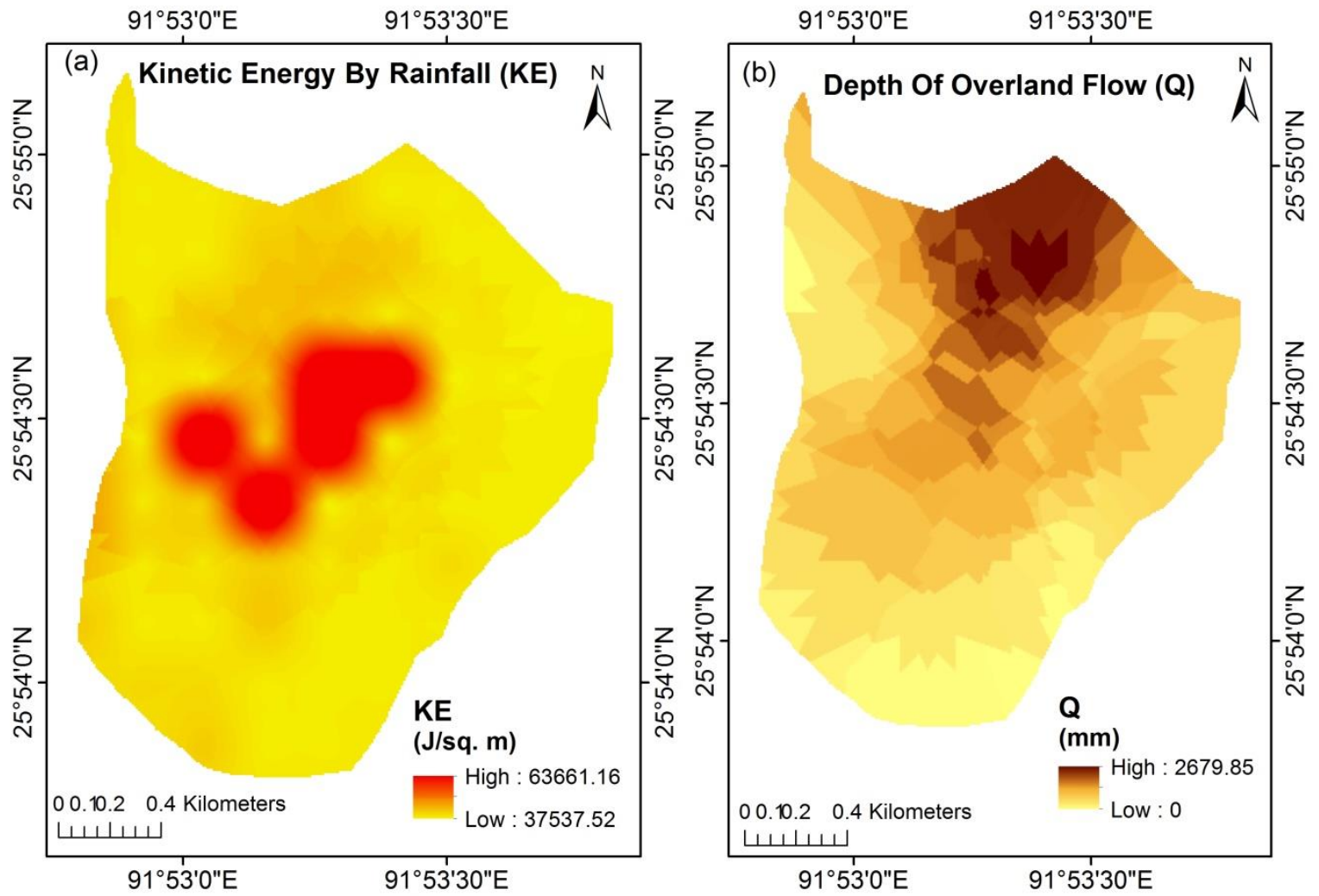

Figure 9. (a) Kinetic energy by raindrop and (b) depth of overland flow. 

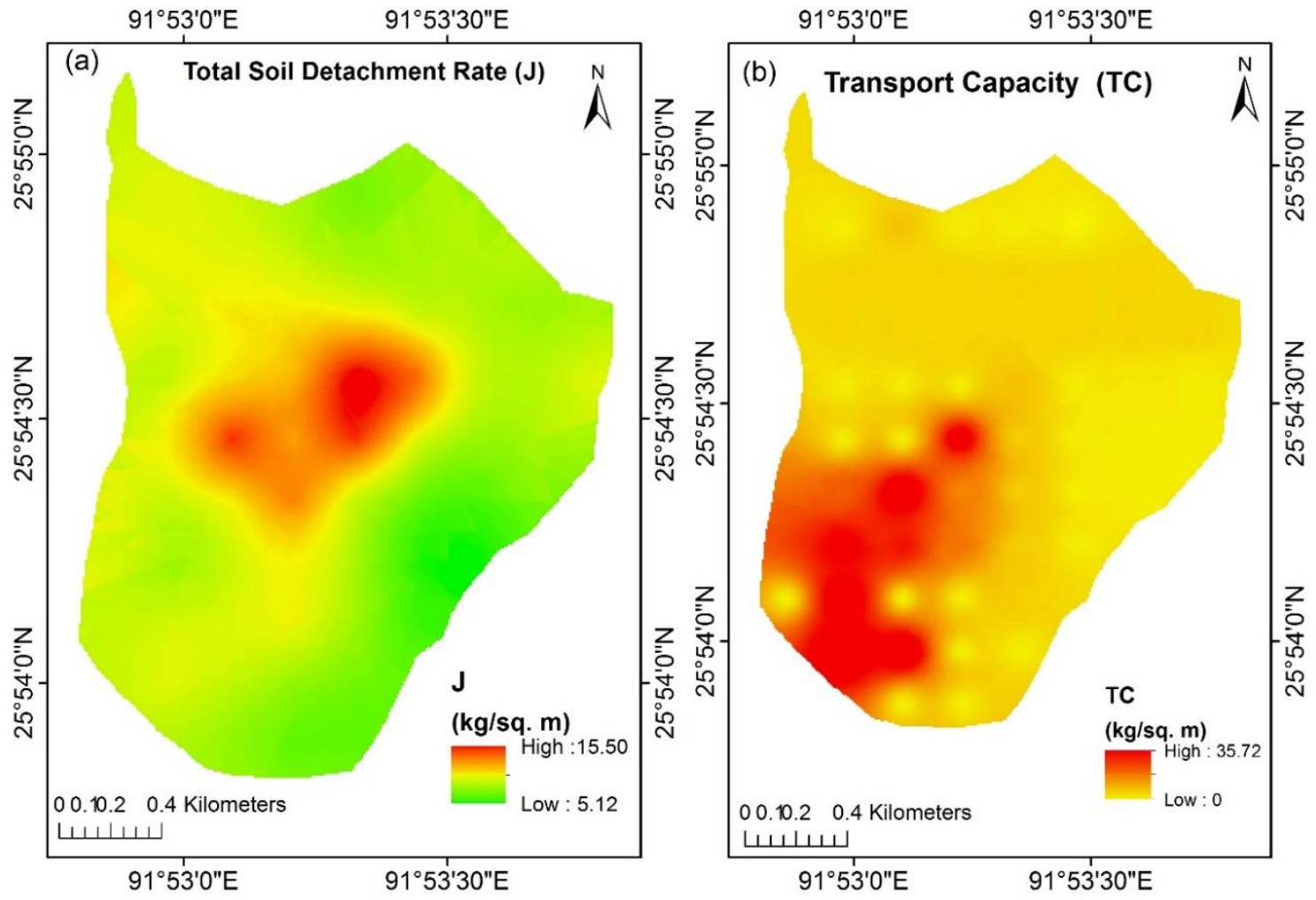

Figure 10. (a) Total soil detachment rate and (b) transport capacity by runoff or overland flow.
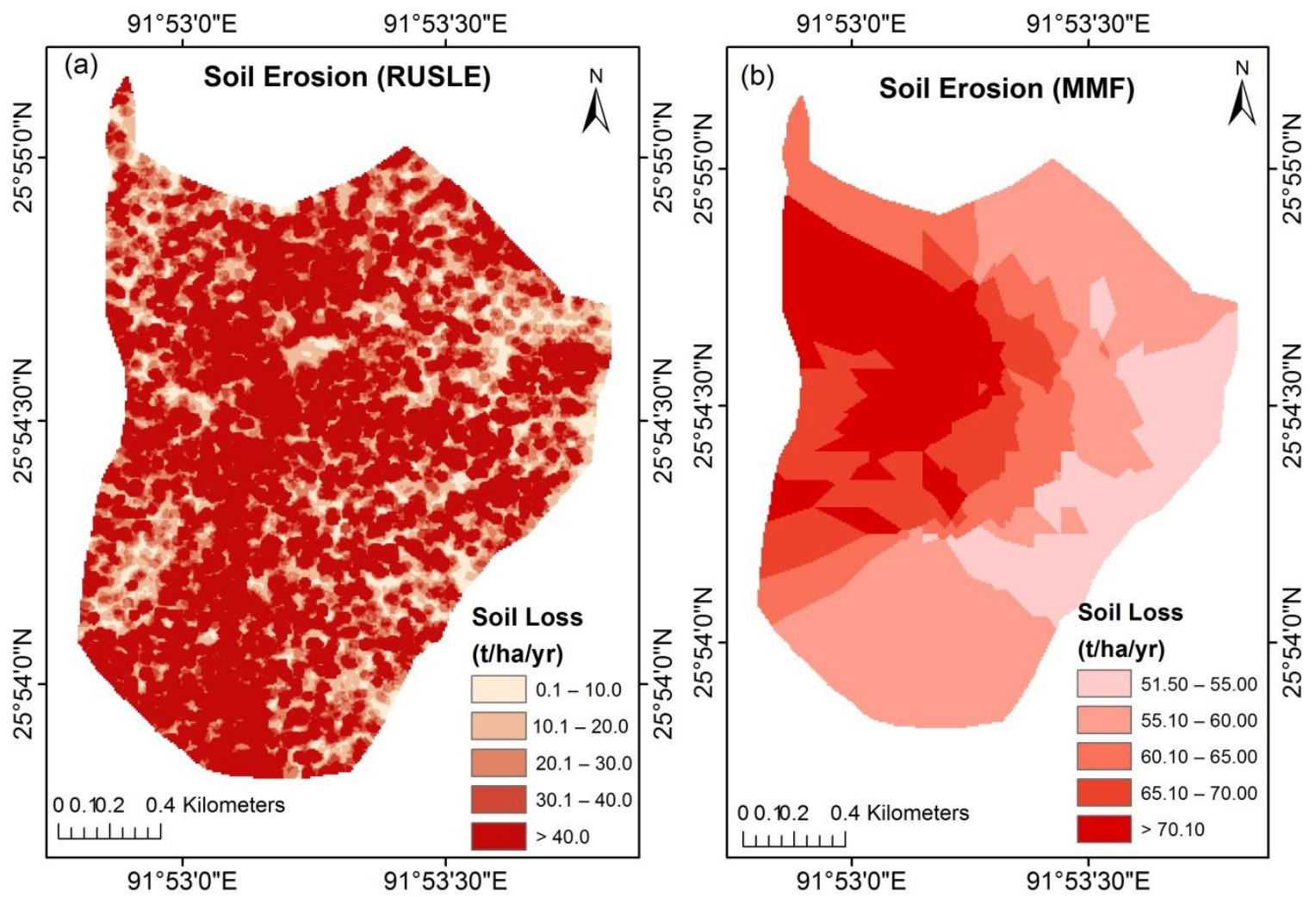

Figure 11. Soil loss estimated by (a) RUSLE and (b) MMF models. 


\subsection{MMF Model}

The soil loss in MMF was determined by calculating various input parameters required in GIS environment. The input parameters of MMF models are shown in Table 4.

Table 4. Input parameters of the MMF model.

\begin{tabular}{|c|c|c|c|c|c|c|c|c|c|c|c|c|}
\hline Factors & $\begin{array}{l}\text { MS } \\
(\%)\end{array}$ & $\begin{array}{c}\text { BD } \\
\left(\mathrm{Mg} \mathrm{m}^{-3}\right)\end{array}$ & $\begin{array}{c}\text { EHD } \\
(\mathrm{m})\end{array}$ & $\begin{array}{l}\mathrm{COH} \\
(\mathrm{KPa})\end{array}$ & $\mathbf{A}$ & $\mathrm{E}_{\mathrm{t}} / \mathrm{E}_{\mathrm{o}}$ & $\begin{array}{l}\text { CC } \\
(\%)\end{array}$ & $\begin{array}{l}\text { GC } \\
(\%)\end{array}$ & $\begin{array}{l}\text { PH } \\
(\mathrm{m})\end{array}$ & $\begin{array}{c}\text { ER } \\
(\mathrm{mm})\end{array}$ & $\begin{array}{c}\mathrm{LD} \\
(\mathrm{mm})\end{array}$ & $\begin{array}{c}\text { DT } \\
(\mathrm{mm})\end{array}$ \\
\hline Range & $0.08-0.45$ & $1.2-1.7$ & $7-15$ & 0-105 & $0-0.35$ & $0.05-0.9$ & $0-70$ & $0-70$ & $0-25$ & $1718.71-2645.71$ & 0-1851.77 & $2645.41-515.62$ \\
\hline Average & 0.25 & 1.32 & 11.57 & 70.59 & 0.25 & 0.5 & 36.87 & 36.87 & 23.88 & 1838.08 & 676.62 & 1165.60 \\
\hline
\end{tabular}

where MS = moisture content, BD = bulk density of topsoil, EHD = effective hydrological depth of soil, COH = cohesion of soil,

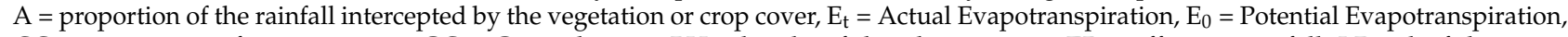
$\mathrm{CC}=$ proportion of canopy cover, $\mathrm{GC}=$ Ground cover, $\mathrm{PH}=$ height of the plant canopy, ER = effective rainfall, $\mathrm{LD}=$ leaf drainage, and DT $=$ direct through fall

The spatial distribution of vegetation canopy cover and height of tree was the vital input for estimation of rainfall kinetic energy in GIS environment and it was found to have an average value of $40402.80\left(\mathrm{~J} \mathrm{~m}^{-2}\right)$ for the study area (Figure 9). The average overland flow (Q) for the study area was found to be $64.66 \mathrm{~mm}$ (Figure 8). During the calibration and validation process of the model, the annual rate of total soil particle detachment $(\mathrm{J})$ ranged from $5.15-15.50\left(\mathrm{~kg} / \mathrm{m}^{2}\right)$ with an average of $5.53\left(\mathrm{~kg} / \mathrm{m}^{2}\right)$, and the annual transport capacity of overland flow (TC) lay between $0-35.72\left(\mathrm{~kg} / \mathrm{m}^{2}\right)$ with an average of $11.50\left(\mathrm{~kg} / \mathrm{m}^{2}\right)$ (Figure 10). This model compares the rate of expected splash detachment (J) with a transport capacity of runoff or overland flow (TC), and J was noted to have lower values and it was used as the soil erosion rate.

\subsection{Overall Comparison of Annual Soil Loss Estimated by RUSLE and MMF Models}

The comparison of the RUSLE and MMF models showed similar trends of soil loss in the study area (Figure 11). Both RUSLE model and MMF model results calculated for the soil erosion rate at the study area showed that the area falls under the severe erosion category. By considering the average annual soil loss from the models, it was found that the MMF model underestimated the soil erosion rate relative to the RUSLE model by $7.72 \%$. The comparison of the RUSLE and MMF models is shown in Table 5.

Table 5. Comparison of annual soil loss estimated by the RUSLE and MMF models.

\begin{tabular}{cccc}
\hline RUSLE Model & MMF Model & \% Difference & Erosion Class \\
\hline $59.94 \mathrm{t} / \mathrm{ha} / \mathrm{yr}$ & $55.30 \mathrm{t} / \mathrm{ha} / \mathrm{yr}$ & 7.74 & Severe erosion risk \\
\hline
\end{tabular}

While considering the RUSLE model, further LULC wise soil loss was estimated (Table 6). Both the models showed that the agricultural land contributed the maximum soil erosion rate in the study catchment. On the other hand, terracing, upland paddy fields, contour bunding, and dense forest are already protected, and they need more time to stabilize. Prioritization was done based on annual soil loss, where $40 \mathrm{t} / \mathrm{ha} / \mathrm{yr}$ annual soil was taken as a benchmark $[42,44,46,47]$ in the unsterilized areas of open forest, agriculture, and scrubland. This implies soil erosion values lesser and greater than this threshold are considered as a low and high erosion risk area respectively (Figure 12). This threshold value was defined by Singh et al. 1992 [47] for the mountainous watershed of India. As mentioned earlier, the prioritization map was derived based on the soil erosion estimates of the RUSLE model. The condition for the management plan was applied in ArcGIS 10.2 environment; it is shown in Table 7. Based on the prioritization map, it can be clearly seen that the prioritization is none for open forests and settlements on the left side of the micro-catchment. An alternative LULC/suggested management plan (Figure 13 and Table 8) was done based on prioritization (rate of soil loss), LULC (like agriculture, open forest, and scrubland), and slope (\%) of the study area. In the ALULC or BMP, the intensive agriculture covers the 
maximum area ( 25.12 ha) whereas afforestation covers 22.57 ha, terracing covers 12.53 ha, and graded/contour bunding covers 7.88 ha area in the watershed.

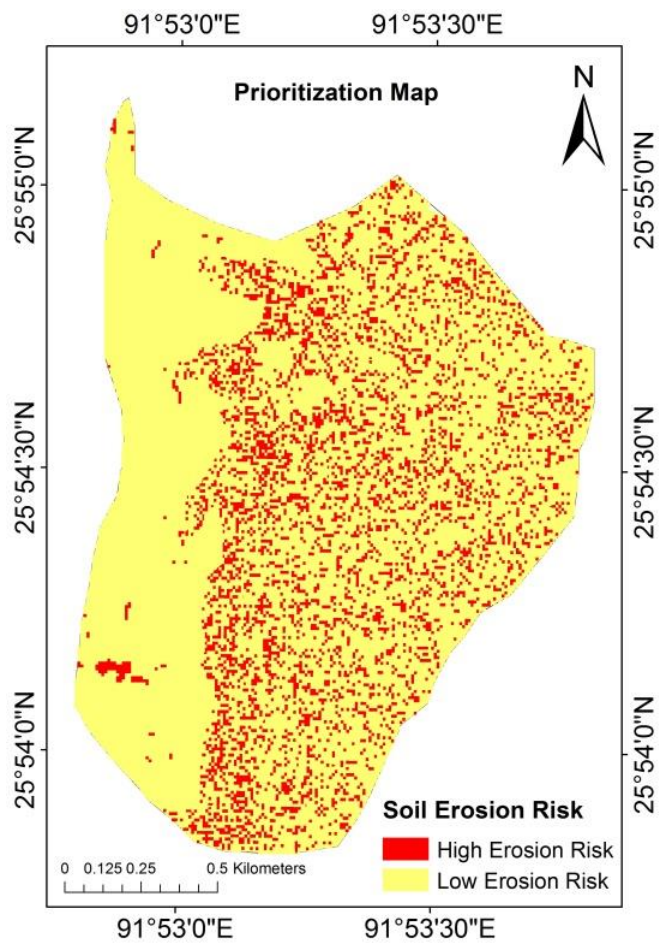

Figure 12. Prioritization of critical area.

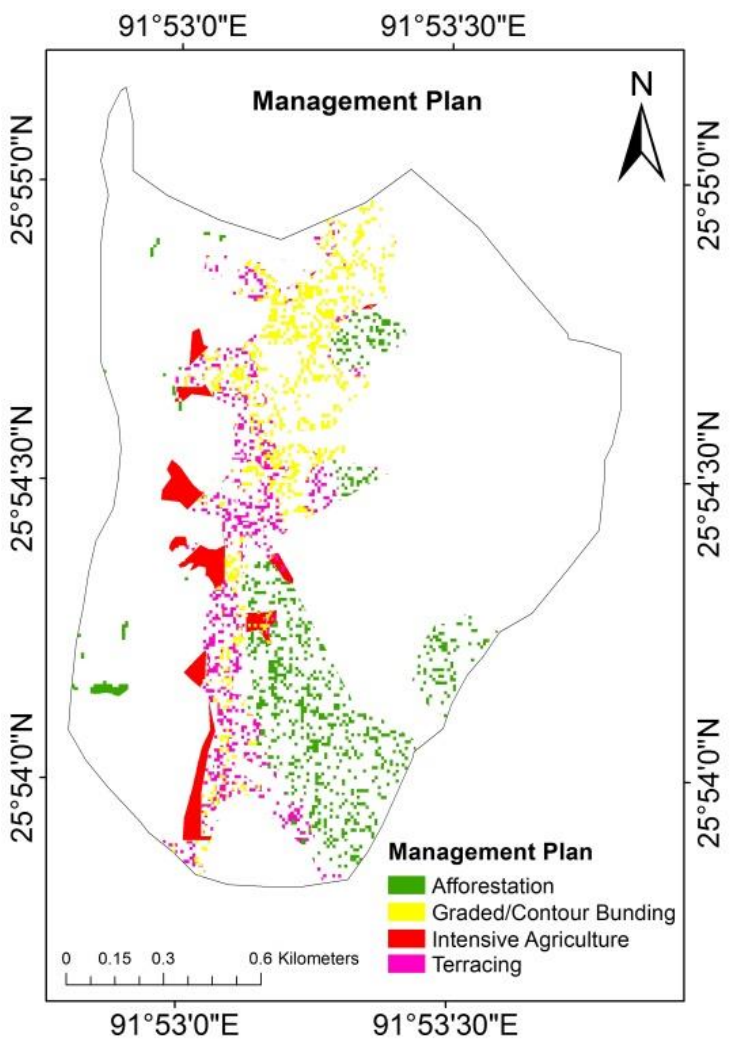

Figure 13. Management plan of the study area. 
Table 6. LULC wise soil loss estimated at the study area.

\begin{tabular}{ccccc}
\hline LULC & $\begin{array}{c}\text { Average } \\
\text { Soil Loss (t/ha/yr) }\end{array}$ & Erosion Area (ha) & Total Area (ha) & \% Area \\
\hline Agriculture & 79.10 & 23.83 & 44.29 & 78.8 \\
Dense forest & 53.76 & 26.45 & 55.15 & 33.80 \\
Open forest & 46.39 & 23.45 & 49.37 & 42.52 \\
Scrubland & 62.67 & 0.26 & 0.19 & 39.01 \\
Terracing & 0.00 & 3.00 & 8.86 & 3.00 \\
Upland paddy field & 15.50 & 0.00 & 4.20 & 0.00 \\
Contour bunding & 0.00 & & & \\
\hline
\end{tabular}

Table 7. Condition for management plan.

\begin{tabular}{|c|c|c|c|c|}
\hline Soil Loss $\left(\mathrm{t} \mathrm{ha}^{-1} \mathrm{yr}^{-1}\right)$ & $>40$ & $>40$ & $>40$ & $<40$ \\
\hline \multirow[t]{2}{*}{ \% slope } & $0-8$ & 8-33 & $>33$ & $0-8$ \\
\hline & Agriculture & Agriculture & Agriculture & Agriculture \\
\hline \multirow[t]{2}{*}{ LULC } & Open forest & & Open Forest & \\
\hline & Scrubland & Scrubland & Scrubland & \\
\hline Management plan & Graded/contour bunding & Terracing & Afforestation & Intensive agriculture \\
\hline
\end{tabular}

Table 8. Management plan of the prioritized area.

\begin{tabular}{cccccc}
\hline & \multicolumn{3}{c}{ Management Plan } \\
\hline LULC & $\begin{array}{c}\text { Graded/Contour } \\
\text { Bunding (ha) }\end{array}$ & Afforestation (ha) & $\begin{array}{c}\text { Intensive } \\
\text { Agriculture (ha) }\end{array}$ & Terracing (ha) & Total Area (ha) \\
\hline Agriculture & 7.50 & - & 25.12 & 4.19 & 36.81 \\
Open Forest & 0.04 & 10.26 & - & - & 10.31 \\
Scrubland & 0.34 & 12.31 & - & 2.34 & 2.99 \\
Total Area (ha) & 7.88 & 22.57 & 25.12 & 12.53 & 68.01 \\
\hline
\end{tabular}

\section{Discussion}

The study area is situated in mountainous regions of India which faces a major problem of soil erosion as is presented in this study. This problem occurs due to high and erratic rainfall [48,49], higher value of soil erodibility, slope length, and crop management factor (as identified in this study). Additionally, little to no conservation practices (terracing and contouring) have been employed in the study area which has led to the high soil erosion. As the watershed is mountainous with a steep slope, it inherits a high slope length factor and consequently high overland flow with high velocity. Slope length is the primary factor influencing soil erosion [50,51] and its impact is complex [52]. As the slope length increases, this leads to the high overland flow and results in the increase in soil erosion and sediment yield in the study area. High rainfall erosivity $(R)$ was found in the study. A higher R value indicates higher kinetic energy of rainfall and surface runoff, which contributes to higher soil erosion [53]. Moreover, the high soil erodibility factor (K) directly increased the rate of soil erosion $[33,37,54]$. The predicted soil erosion for the study area was close to the other studies in India and other countries' hilly watersheds [54-56]. Soil erosion leads to loss of soil nutrients and a decrease in soil fertility that should give significant attention during the construction of the conservation management plan [57]. Based on soil loss and land use, the watershed is prioritized for conservation measures. The management plan for soil conservation and watershed development by reducing soil loss was made based on the slope, LULC, and soil loss classes. High soil erosion was found from the agricultural land and the management plans were prepared accordingly. For this, a change in the existing agricultural cultivation system should be done with intensive agriculture, contour bunding, and terracing. The conservation structures restrict soil erosion by reducing the overland 
flow. The contour bunding and terracing reduce the slope length and also increase the infiltration capacity of the soil.

Prior to the comparison of the RUSLE and MMF models, both models were calibrated (2010-2015) and validated (2016-2019) against observed soil loss (measured at the catchment outlet). The model parameters were adjusted manually during model calibration. Two model parameters $(\alpha$ and $\beta$ ) and one model parameter (plant height) were used in model calibration for the RUSLE and MMF models, respectively. While $\alpha$ and $\beta$ parameters relate NDVI and the $C$ factor, they are sensitive to land use type. Throughout the study catchment, $\alpha$ and $\beta$ parameters varied with an average value of 2.06 and 0.97 , respectively. Similarly, the plant height parameter in MMF model varied spatially due to different land use types across the catchment. As displayed in Figure 5, the calibrated values for different land use types ranged from 0 (for water body) to 23.54 (dense forest). These calibrated values (both RUSLE and MMF model parameters) were used in model validation for the year 2016-2019, where the model simulated soil erosion was compared against the observed soil loss. The results demonstrated NSE, MAE and RMSE values of $0.73,0.95 \mathrm{t} / \mathrm{ha} / \mathrm{yr}, 1.51 \mathrm{t} / \mathrm{ha} / \mathrm{yr}$, and 0.71, $3.69 \mathrm{t} / \mathrm{ha} / \mathrm{yr}, 3.85 \mathrm{t} / \mathrm{ha} / \mathrm{yr}$ for RUSLE and MMF models, respectively, during model validation (Table 3). These results indicate that both models are well in agreement with the observed soil loss in the study catchment with minor superior performance observed for the RUSLE model.

With regards to the BMP strategies to combat the soil erosion within the microcatchment, RUSLE method was used to identify the prioritization areas within the catchment. The prioritization plot (Figure 12) displays the priority areas are more dominant in the right-hand side of the catchment which is predominantly dense forest, scrubland, agriculture, contour bunding, and upland paddy field types of LULC. The suggested management plan (Figure 13) showcases that afforestation is mainly suggested for the open forest LULC, contour bunding is recommended for agricultural LULC within steep slopes, and terracing is suggested for both agricultural lands as well as scrublands (depending on slopes). Table 7 displays the total area under agricultural LULC suggested for contour bunding and terracing are 7.50 ha and 4.19 ha, respectively. Similarly, for open forest LULC, contour bunding and afforestation are suggested for 0.04 ha and 10.26 ha, respectively. On the other hand, for scrubland LULC, 0.34 ha, 12.31 ha, and 8.34 ha land area are suggested for contour bunding, afforestation, and terracing, respectively. This indicates that a significant area is under severe erosion in case of scrubland which requires afforestation. Nevertheless, proper management practices are paramount in the study micro-catchment for reducing soil loss irrespective of the LULC.

A similar study was done using RUSLE model at West Bengal, India [58] for alike land use class of this study and found an increase in the rate of erosion with increasing areas in dense forests $\left(134 \mathrm{t} / \mathrm{ha} / \mathrm{yr}, 55 \mathrm{~km}^{2}\right)$, degraded forests $\left(169 \mathrm{t} / \mathrm{ha} / \mathrm{yr}, 137 \mathrm{~km}^{2}\right)$, and settlement areas $\left(30 \mathrm{t} / \mathrm{ha} / \mathrm{yr}, 105 \mathrm{~km}^{2}\right)$, which is closely in line with our results. Furthermore, several other studies at different geographic domains (mountainous and plain) of India such as in the Urmodi river watershed at Maharashtra, India with an area of $70.22 \mathrm{~km}^{2}$, found areas to be under very severe erosion risk ( $>80 \mathrm{t} / \mathrm{ha} / \mathrm{yr}$ ) [59]. In another watershed (Konar river basin), using RUSLE, the soil loss was found to be in the very high category of 5-40 t/ha/yr [60]. Synonymously, studies on similar slope and land use catchments in countries like Sri Lanka, Malaysia, and Rwanda also revealed high rate of soil erosion [55,61,62]. Moreover, in Rwanda, $91 \%$ of the study area comprised of slope more than $15^{\circ}$ and the average soil loss was in the range of 31-41 t/ha/yr [55], which is consistent with this study since $60 \%$ of the area is comprised of high slope $\left(>25^{\circ}\right)$ and falls under severe erosion classes $(>40 \mathrm{t} / \mathrm{ha} / \mathrm{yr})$. The present study enabled us to prioritize the different segments of watershed based on soil erosion risk. This will help in proper land uses and planning conservation practices in the future extension of agricultural activities. The alternate land uses for the watershed are expected to be followed by the farming communities to achieve sustainability in agricultural productions. The results from the study will help in understanding the erosion risk of watershed vis-à-vis land uses so that the same can be extrapolated to other watersheds with 
similar landforms, soil, and land use. These findings from other studies are in line with the findings of this study, which indicates the wide applicability of these soil erosion models in larger catchment sizes. This study on the other hand indicates the applicability for smaller sized catchment as well for evaluating BMPs.

\section{Conclusions}

The average annual soil erosion estimated with RUSLE was found to be $59.94 \mathrm{t} / \mathrm{ha} / \mathrm{yr}$, whereas the MMF model estimated soil loss as $55.30 \mathrm{t} / \mathrm{ha} / \mathrm{yr}$. Since there was an absolute difference of only $7.74 \%$, the estimates made by both the models can be considered at par. At this range of soil loss, the watershed can be classified as a severely eroded catchment and it needs suitable land use management plans to combat the severe soil erosion. The soil erosion was found to be highest in the agriculture dominated area $(79.10 \mathrm{t} / \mathrm{ha} / \mathrm{yr})$, followed by scrubland $(62.67 \mathrm{t} / \mathrm{ha} / \mathrm{yr})$. Under the alternative management plan, considering the threshold of $40 \mathrm{t} / \mathrm{ha} / \mathrm{yr}$, intensive agriculture is suggested only in those areas having a slope less than $8 \%$. Within the study watershed, 68.01 ha area is prioritized for soil conservation measures to reduce the erosion potential under proposed alternative land uses. The results from the study will help in understanding the erosion risk of watershed vis-à-vis land uses so that the same can be extrapolated to other watersheds with similar landforms, soil, and land uses. These findings will aid in implementing robust BMPs in the hilly and mountainous regions in the world.

Author Contributions: S.D. conducted the study with suggestions from P.K.B. and S.D.; P.K.B. and P.D. wrote the original and the revised manuscript; and P.K. reviewed and commented on the original draft of the manuscript. All authors have read and agreed to the published version of the manuscript.

Funding: This research received no external funding.

Institutional Review Board Statement: The study was the partial fulfilment of Post Graduate (PG) degree work of Susanta Das and it was approved by the Indira Gandhi Krishi Vishwavidyalaya research committee in 2017.

Informed Consent Statement: Not applicable.

Data Availability Statement: The data presented in this study are available on request from the corresponding author. The data are not publicly available since they are collected by the first author of this paper.

Acknowledgments: The authors would like to acknowledge Ranjit Das of North Eastern Space Applications Centre (NESAC), Umiam, Meghalaya, India and M.P. Tripathi of Indira Gandhi Krishi Vishwavidyalaya, Raipur, Chhattisgarh, India for their assistance and suggestions while conducting the study.

Conflicts of Interest: The authors declare no conflict of interest.

\section{References}

1. Ighodaro, I.D.; Lategan, F.S.; Yusuf, S.F.G. The impact of soil erosion on agricultural potential and performance of Sheshegu community farmers in the Eastern Cape of South Africa. J. Agric. Sci. 2013, 5, 140-147. [CrossRef]

2. Koirala, P.; Thakuri, S.; Joshi, S.; Chauhan, R. Estimation of Soil Erosion in Nepal Using a RUSLE Modelling and Geospatial Tool. Geoscience 2019, 9, 147. [CrossRef]

3. Lal, R.; Singh, B.R. Effects of Soil Degradation on Crop Productivity in East Africa. J. Sustain. Agric. 1998, 13, 15-36. [CrossRef]

4. Hategekimana, Y.; Allam, M.; Meng, O.; Nie, Y.; Mohamed, E. Quantification of Soil Losses along the Coastal Protected Areas in Kenya. Land 2020, 9, 137. [CrossRef]

5. Claessens, L.; Van Breuge, P.; Notenbaert, A.; Herrero, M.; Van De Steeg, J. Mapping potential soil erosion in East Africa using the Universal Soil Loss Equation and secondary data. IAHS-AISH Publ. 2008, 325, 398-407.

6. Ganasri, B.P.; Ramesh, H. Assessment of soil erosion by RUSLE model using remote sensing and GIS-A case study of Nethravathi Basin. Geosci. Front. 2016, 7, 953-961. [CrossRef]

7. Sujatha, E.; Sridhar, V. Spatial Prediction of Erosion Risk of a Small Mountainous Watershed Using RUSLE: A Case-Study of the Palar Sub-Watershed in Kodaikanal, South India. Water 2018, 10, 1608. [CrossRef]

8. Reichmann, O.; Chen, Y.; Iggy, L.M. Spatial model assessment of P transport from soils to waterways in an Eastern Mediterranean Watershed. Water 2013, 5, 262-279. [CrossRef] 
9. Ozsahin, E.; Duru, U.; Eroglu, I. Land use and land cover changes (LULCC), a key to understand soil erosion intensities in the Maritsa Basin. Water 2018, 10, 335. [CrossRef]

10. Deb, P.; Kiem, A.S.; Willgoose, G. A linked surface water-groundwater modelling approach to more realistically simulate rainfall-runoff non-stationarity in semi-arid rgions. J. Hydrol. 2019, 575, 273-291. [CrossRef]

11. Chandra, S.; Manisa, P. Application of RUSLE model for soil loss estimation of Jaipanda watershed, West Bengal. Spat. Inf. Res. 2017, 25, 399-409.

12. Woldemariam, G.; Iguala, A.; Tekalign, S.; Reddy, R. Spatial Modeling of Soil Erosion Risk and Its Implication for Conservation Planning: The Case of the Gobele Watershed, East Hararghe Zone, Ethiopia. Land 2018, 7, 25. [CrossRef]

13. Reitsma, K.D.; Dunn, B.H.; Mishra, U.; Clay, S.A.; DeSutter, T.; Clay, D.E. Land-use change impact on soil sustainability in a climate and vegetation transition zone. Agron. J. 2015, 107, 2363-2372. [CrossRef]

14. Perez-Molina, E.; Sliuzas, R.; Flacke, J.; Jetten, V. Developing a cellular automata model of urban growth to inform spatial policy for flood mitigation: A case study in Kampala, Uganda. Comput. Environ. Urban Syst. 2017, 65, 53-65. [CrossRef]

15. Pelacani, S.; Marker, M.; Rodolfi, G. Simulation of soil erosion and deposition in a changing land use: A modelling approach to implement the support practice factor. Geomorphology 2008, 99, 329-340. [CrossRef]

16. Wischmeier, W.H.; Smith, D.D. Predicting Rainfall Erosion Losses from Cropland East of the Rocky Mountains; U. S. Dept. of Agric. AH, 282.U.S.; Government Printing Office: Washington, DC, USA, 1965.

17. Morgan, R.P.C.; Morgan, D.D.V.; Finney, H.J. A predictive model for the assessment of erosion risk. J. Agric. Eng. Res. 1984, 30, 245-253. [CrossRef]

18. Renard, K.G.; Foster, G.R.; Weesies, G.A.; Porter, J.P. RUSLE: Revised universal soil loss equation. J. Soil Water Conserv. 1991, $46,30-33$.

19. Mendoza-ponce, A.; Corona-núñez, R.; Kraxner, F.; Leduc, S.; Patrizio, P. Identifying effects of land use cover changes and climate change on terrestrial ecosystems and carbon stocks in Mexico. Glob. Environ. Chang. 2018, 53, 12-23. [CrossRef]

20. Alphan, H.; Derse, M.A. Change detection in Southern Turkey using normalized di_erence vegetation index (NDVI). J. Environ. Eng. Landsc. Manag. 2013, 21, 12-18. [CrossRef]

21. Moran-Tejeda, E.; Zabalza, J.; Rahman, K.; Gago-Silva, A.; López-Moreno, J.I.; Vicente-Serrano, S.; Lehmann, A.; Tague, C.L.; Beniston, M. Hydrological impacts of climate and land-use changes in a mountain watershed: Uncertainty estimation based on model comparison. ECO Hydrol. 2014, 8, 1396-1416. [CrossRef]

22. Taye, G.; Vanmaercke, M.; Poesen, J.; Van Wesemael, B.; Tesfaye, S.; Teka, D.; Nyssen, J.; Deckers, J.; Haregeweyn, N. Determining RUSLE P- and C-factors for stone bunds and trenches in rangeland and cropland, North Ethiopia. L. Degrad. Dev. 2018, 29, 812-824. [CrossRef]

23. Zeng, C.; Wang, S.; Bai, X.; Li, Y.; Tian, Y.; Li, Y.; Wu, L.; Luo, G. Soil erosion evolution and spatial correlation analysis in a typical karst geomorphology using RUSLE with GIS. Solid Earth 2017, 8, 721-736. [CrossRef]

24. Lazzari, M.; Gioia, D.; Piccarreta, M.; Danese, M.; Lanorte, A. Sediment yield and erosion rate estimation in the mountain catchments of the Camastra artificial reservoir (Southern Italy): A comparison between different empirical methods. Catena 2015, 127, 323-339. [CrossRef]

25. Dimotta, A.; Lazzari, M.; Cozzi, M.; Romano, S. Soil Erosion Modelling on Arable Lands and Soil Types in Basilicata, Southern Italy; Gervasi, O., Ed.; ICCSA 2017, Part V, Lecture Notes in Computer Science LNCS; Springer: Cham, Switzerland, 2017; Volume 10408, pp. $57-72$.

26. Meyer, L.; Wischmeier, W. Mathematical simulation of the process of soil erosion by water. Trans. ASAE 1969, 12, 754-758.

27. Wischmeier, W.H.; Smith, D.D. Predicting Rainfall Erosion Losses-A Guide to Conservation Planning; AH-537; U.S. Department of Agriculture: Beltsville, MD, USA, 1978.

28. Morgan, R.P.C. Soil Erosion and Conservation, 3rd edition. Eur. J. Soil Sci. 2005, 56, 681-687.

29. Ghosh, S.; Guchhait, S.K. Soil loss estimation through USLE and MMF methods in the Lateritic Tracts of Eastern Plateau Fringe of Rajmahal Traps, India. Ethiop. J. Environ. Stud. Manag. 2012, 5, 529-541. [CrossRef]

30. Deb, P.; Kiem, A.S. Evaluation of rainfall-runoff model performance under non-stationary hydroclimatic conditions. Hydrol. Sci. J. 2020, 65, 1667-1684. [CrossRef]

31. Behera, R.N.; Nayak, D.K.; Andersen, P.; Måren, I.E. From jhum to broom: Agricultural land-use change and food security implications on the Meghalaya Plateau, India. Ambio 2015, 45, 63-77. [CrossRef]

32. Saha, R.; Chaudhary, R.S.; Somasundaram, J. Soil Health Management under Hill Agroecosystem of North East India. Appl. Environ. Soil Sci. 2012, 2012, 696174. [CrossRef]

33. Das, S.; Bora, P.K.; Katre, P. Determining and Mapping of Soil Erodibility Index for Nongpoh Watershed. Indian J. Hill Farming 2019, 32, 27-33.

34. Lee, S. Geological application of geographic information system. Korea Inst. Geosci. Min. Resour. 2014, 9, $109-118$.

35. Silalahi, F.E.S.; Pamela, A.Y.; Hidayat, F. Landslide susceptibility assessment using frequency ratio model in Bogor, West Java, Indonesia. Geosci. Lett. 2019, 6, 10. [CrossRef]

36. Olaniya, M.; Bora, P.K.; Das, S.; Chanu, P.H. Soil erodibility indices under different land uses in Ri-Bhoi district of Meghalaya (India). Sci. Rep. 2020, 10, 14986. [CrossRef] [PubMed]

37. Das, S.; Sarkar, R.; Bora, P.K. Comparative study of estimation of soil erodibility factor for the lower Transact of Ranikhola watershed of east Sikkim. J. Plant Develop. Sci. 2018, 10, 317-322. 
38. Wischmeier, W.H.; Johnson, C.B.; Cross, B.V. A soil erodibility nomograph for farm-land and construction sites. J. Soil Water Conserv. 1971, 26, 189-193.

39. Deb, P.; Debnath, P.; Denis, A.F.; Lepcha, O.T. Variability of soil physicochemical properties at different agroecological zones of Himalayan region: Sikkim, India. Env. Dev. Sustain. 2019, 21, 2321-2339. [CrossRef]

40. Polykretis, C.; Alexakis, D.D.; Grillakis, M.G.; Manoudakis, S. Assessment of intra-annual and inter-annual variabilities of soil erosion in Crete Island (Greece) by incorporating the dynamic "Nature" of R and C-Factors in RUSLE modeling. Remote Sens. 2020, 12, 2439. [CrossRef]

41. Van der Knijff, J.M.; Jones, R.J.A.; Montanarella, L. Soil Erosion Risk Assessment in Europe; EUR 19044 EN; Office for Official Publications of the European Communities: Luxembourg, 2000; p. 34.

42. Mondal, A.; Khare, D.; Kundu, S. A comparative study of soil erosion modelling by MMF, USLE and RUSLE. J. Geocarto Int. 2018, 33, 89-103. [CrossRef]

43. Dabral, P.P.; Baithuri, N.; Pandey, A. Soil erosion assessment in a hilly catchment of North Eastern India using USLE, GIS and remote sensing. Water Resour. Manag. 2008, 22, 1783-1798. [CrossRef]

44. Srivastava, R.K.; Sharma, H.C.; Raina, A.K. Suitability of soil and water conservation measures for watershed management using geographical information system. J. Soil Water Conserv. 2010, 9, 148-153.

45. Moriasi, D.N.; Arnold, J.G.; Van Liew, M.W.; Bingner, R.L.; Harmel, R.D.; Veith, T.L. Model Evaluation Guidelines for Systematic Quantification of Accuracy in Watershed Simulations. Trans. ASABE 2007, 50, 885-900. [CrossRef]

46. Pandey, A.; Mathur, A.; Mishra, S.K.; Mal, B.C. Soil erosion modeling of a Himalayan watershed using RS and GIS. Environ. Earth Sci. 2009, 59, 399-410. [CrossRef]

47. Singh, G.; Babu, R.; Narain, P.; Bhushan, L.S.; Abrol, I.P. Soil erosion rates in India. J. Soil Soil Water Conserv. 1992, 47, 97-99.

48. Yadav, S.; Deb, P.; Kumar, S.; Pandey, V.; Pandey, P.K. Trends in major and minor meteorological variables and their influence on reference evapotranspiration for mid Himalayan region at east Sikkim, India. J. Mt. Sci. 2016, 13, 302-315. [CrossRef]

49. Marak, J.D.; Sarma, A.K.; Bhattacharjya, R.K. Innovative trend analysis of spatial and temporal rainfall variations in Umiam and Umatru watersheds in Meghalaya, India. Theor. Appl. Climatol. 2020, 142, 1397-1412. [CrossRef]

50. Wilkinson, M.T.; Humphreys, G.S. Slope aspect, slope length and slope inclination controls of shallow soils vegetated by sclerophyllous heath-Links to long-term landscape evolution. Geomorphology 2006, 76, 347-362. [CrossRef]

51. Liu, B.Y.; Nearing, M.A.; Shi, P.J.; Jia, Z.W. Slope length effects on soil loss for steep slopes. Soil Sci. Soc. Am. J. 2000, 64, 1759-1763. [CrossRef]

52. Han, Z.; Zhong, S.; Ni, J.; Shi, Z.; Wei, C. Define the Slope Length of Newly Reconstructed Gentle-Slope Lands in Hilly Mountainous Regions. Sci. Rep. 2019, 9, 4676. [CrossRef]

53. Balasubramani, K.; Gomathi, M.; Bhaskaran, G.; Kumaraswamy, K. GIS-based spatial multi-criteria approach for characterization and prioritization of micro-watersheds: A case study of semi-arid watershed, South India. Appl. Geomat. 2019, 11, $289-307$. [CrossRef]

54. Pal, S.C.; Chakrabortty, R. Simulating the Impact of Climate Change on Soil Erosion in Sub-Tropical Monsoon Dominated Watershed Based on RUSLE, SCS Runoff and MIROC5 Climatic Model. Adv. Space Res. 2019, 64, 352-377. [CrossRef]

55. Dissanayake, D.; Morimoto, T.; Ranagalage, M. Accessing the soil erosion rate based on RUSLE model for sustainable land use management: A case study of the Kotmale watershed, Sri Lanka. Modeling Earth Syst. Environ. 2018, 5, 291-306. [CrossRef]

56. Ostovari, Y.; Moosavi, A.A.; Pourghasemi, H.R. Soil loss tolerance in calcareous soils of a semi-arid region: Its evaluation, prediction, and influential parameters. Land Degrad. Develop. 2020, 31, 2156-2167. [CrossRef]

57. Shen, Z.Y.; Gong, Y.W.; Li, Y.H.; Liu, R.M. Analysis and modeling of soil conservation measures in the Three Gorges Reservoir Area in China. Catena 2010, 81, 104-112. [CrossRef]

58. Bhattacharya, R.K.; Das Chatterjee, N.; Das, K. Land use and land cover change and its resultant erosion susceptible level: An appraisal using RUSLE and Logistic Regression in a tropical plateau basin of West Bengal, India. Environ. Dev. Sustain. 2020, 1-36. [CrossRef]

59. Bagwan, W.A.; Gavali, R.S. Delineating changes in soil erosion risk zones using RUSLE model based on confusion matrix for the Urmodi river watershed, Maharashtra, India. Modeling Earth Syst. Environ. 2020, 1-14. [CrossRef]

60. Rajbanshi, J.; Bhattacharya, S. Assessment of soil erosion, sediment yield and basin specific controlling factors using RUSLE-SDR and PLSR approach in Konar river basin, India. J. Hydrol. 2020, 587, 124935. [CrossRef]

61. Islam, M.R.; Jaafar, W.Z.W.; Hin, L.S.; Osman, N.; Karim, M.R. Development of an erosion model for Langat River Basin, Malaysia, adapting GIS and RS in RUSLE. Appl. Water Sci. 2020, 10, 1-11. [CrossRef]

62. Byizigiro, R.V.; Rwanyiziri, G.; Mugabowindekwe, M.; Kagoyire, C.; Biryabarema, M. Estimation of Soil Erosion Using RUSLE Model and GIS: The Case of Satinskyi Catchment, Western Rwanda. Rwanda J. Eng. Sci. Technol. Environ. 2020, 3. [CrossRef] 